\title{
PROVIDING SECURITY FOR THE INSTITUTIONAL ENVIRONMENT OF THE FINANCIAL SYSTEM OF SUSTAINABLE USE OF NATURAL RESOURCES AND CONSERVATION OF BIODIVERSITY
}

\section{Sergiy Petrukha ${ }^{1}$ \\ Mykola Korolenko}

DOI: https://doi.org/10.30525/978-9934-588-53-2-9

Abstract. The study determines that, in addition to socio-economic, political and cultural relations, the mankind is united, in the first turn, by being in a closed space - on the planet Earth. A space, in accordance with the law of relativity, becomes increasingly narrower with developing new technologies and means of communication. The nature does not recognize state and administrative borders and the efforts of only one or several states are not able to prevent an ecological crisis and give tangible positive results. Understanding these processes dictates the trends in the environment, modernization of active financing of its reproduction, provision of the ecological balance and biodiversity. The purpose of this work is to discover and substantiate possible mechanisms for providing security of the financial system, in general, and the bank (both commercial and state one) functioning in the stock market, in particular, not entering into a financial, economic and social confrontation with their specific function - providing financing for sustainable use of natural resources and conservation of biodiversity within the framework of the global ecological initiative. In the furtherance of this goal, the following methods have been used: comparative analysis and synthesis, grouping of actual data and sample observations. This has made it possible to determine that the processes of financial globalization and liberalization of capital movement are actively going on in the world economy and the total volume of obligations on financial instruments

\footnotetext{
${ }^{1}$ Candidate of Economic Sciences,

Associate Professor at the Department of Financial and Economic Security,

"KROK" University, Ukraine

${ }^{2}$ Postgraduate Students,

SESE "The Academy of Financial Management", Ukraine
} 
exceeds the indicator of the world GDP by ten-folds. Strengthening international ties takes place against the background of the outrunning growth of financial markets of countries with rapidly developing economies and concentration of the bulk of monetary resources in conglomerates, which dizzying expansion often comes with the growth of instability and riskogenics of activities of the financial system institutions.

Theoretical and methodological approaches based on the principles of the global ecological initiative, socio-oriented activities of acceptors of natural and land scape resources, laid as the basis for the architectonics of financing of reproduction of the natural and raw material base of the western system, are hardly applicable to solving domestic tasks of sustainable use of natural resources because the basis for them is formed by the ideas, first of all, of recreational use of depressed territories and only after that - of conservation of biodiversity, while the high-priority task of the Ukrainian system is an efficient building of a 4D model: "sustainable use of natural resources - providing biodiversity - putting the territories out of depression forming security of the functioning of the financial donor". In the Ukrainian financial and economic realities colored by stagnation of the economy due to the COVID-19 coronavirus pandemic, by reducing in budget spending on building the system of sustainable use of natural resources, ecological balance and conservation of biodiversity, carrying out of land reform as well as low financial capability of amalgamated territorial communities bring the banking sector, among the variety of sources of financing, to a forefront, the institutional environment of which - the banking sector - to a different efficiency extent, is able to additionally accumulate monetary flows in the stock market.

Considering the institutional environment of the financial system as a whole of activities of the bank in the stock market has made possible to tie, from a new, previously inexperienced perspective, with a financial thread, which mass determines the level of its security and sustainability of the functioning, the systems of financial support of reproduction of the natural and raw material base within the framework of the global ecological initiative, as well as substantiate the necessity of further research of the functioning and provision of security for the institutional environment of the financial system of sustainable use of natural resources and conservation of biodiversity within the framework of the Dodd-Frank Act and the European MiFID II Directive. 


\section{Introduction}

One of the characteristic features of the present stage of development of society is strengthening an anthropogenic impact on the environment. This process comes with synergistic effects and results in worsening the quality of the environment that results, in the long-term, in reducing in biodiversity, forming additional natural and anthropogenic barriers including ecological and sectoral threats, first, to the entities, the activities of which are tied to using natural and landscape resources, forming crisis phenomena in achieving nationally prioritized UN Global Sustainable Development Goals by 2030 , in particular, a "society - environment - institutional environment of the financial system - sustainable development strategy" quarter. Pride of place in this quarter goes to the financial system institutions filling the strategic initiatives of the Law of Ukraine "On Basic Principles (Strategy) of the State Environmental Policy of Ukraine by 2030", concepts of the nationwide program of conservation of biodiversity for 2005-2025 and implementation of the state policy in climate change by 2030, the National Plan of Action to Combat Land Degradation and Desertification, with financial resources, forming an effect of bound systems, which movement is limited by the volume of monetary resources, their availability, security of the functioning of a donor - banking system, including a donor actively operating in the stock market.

Biodiversity, by which the whole variety of life forms on earth, millions of species of plants, animals, microorganisms with their sets of genes and complex ecosystems establishing a wildlife are meant, is impacted by human activities, not only directly using biological resources (genetic resources, organisms or their parts, populations or any other biotic ecosystem components having actual or potential usefulness or value for the mankind) but also having an impact on any component of the nature (climate, earth's surface relief, surface rocks, surface, ground and soil waters, etc.). These are industry, and agriculture, and forestry, and transport, etc. In accordance with this, biodiversity becomes extremely vulnerable to a human and strong dependency on the availability of monetary funds to provide their protection, reproduction, process manageability and effects of anthropogenic environment transformation.

Processes of financial globalization and capital movement liberalization are actively going on in the world economy. Strengthening international 
ties takes place against the background of the outrunning growth of financial markets of countries with rapidly developing economies and concentration of the bulk of monetary resources in conglomerates, which dizzying expansion often comes with growth in instability and riskogenics of activities of the financial system institutions.

After the global financial and economic recession of 2008-2010 and appearance of outlines of a coronavirus crisis at the end of the first quarter of 2020, activities of financial intermediaries have not declined, as evidenced by the positive dynamics in the world financial market. According to data of the Bank for International Settlements, the total volume of obligations on financial instruments exceeds the indicator of the world GDP by tenfolds. Meanwhile, many years' recession of the world economy has been directly tied to exponential trends for development of the financial system and increasing complexity of its regulation. The specifics of the present phenomena, in particular, caused by the COVID-19 coronavirus pandemic crisis, promote changing in ideas of cyclicality of the economy influenced by the environment, biodiversity and of the nature of financial risks of activities of the banking sector as an element of the financial system in the stock market. Subject to the scale of the impact of the financial system on macroeconomic imbalances along with the problems of use of natural resources, the scientists' attention is focused on solving the tasks tied to development of technologies of prevention of systematic risks of the banking sector activities in the stock market.

The development of the financial systems to provide sustainable use of natural resources, ecological balance, conservation of biodiversity along with appearance of new operations and technologies (resulted from implementation, by the stakeholders, of goals established in the Public Finance Management System Reform Strategy 2017-2020, Fundamentals of the Strategy of the Ukrainian Financial Sector Development until 2025) stipulates the necessity to search for universal models of regulation of activities of participants of the financial sector, optimal anti-crisis measures, instruments for management and minimization of risks of the functioning of banks-donors of sustainable use of natural resources and protection of the environment, first of all, in balancing the goals and tasks of "financial" and "natural resource" mega-, loco- and niche strategies. The activation of scientists in this field promotes convergence of concepts of economic 
schools, which positions touch in terms of recognition of the merits of using the financial system along with a prudential policy for increasing in the efficiency of the functioning and regulation of the use of natural resources. In light of present challenges, it becomes important to solve the problem of security of the functioning of the financial sector (in particular, banks commercial and state ones) for the stable provision, with financial resources, of sustainable use of natural resources, ecological balance and conservation of biodiversity that emphasizes the relevance of the selected research topic.

Theoretical research of the functioning, regulation and provision of financial and economic security of the financial system contains in works of foreign scientists: F. Abergel, G. Akerlof, T. Baker, A. N. Berger, E. Brigham, P. Walker, S. Gading, E. Gapenski, R. de George, R. Easterly, C. Claeys, P. Krugman, D. Mashiandro, F. S. Mishkin, A. M. Melecky, N. Roubini, J. E. Stiglitz, P. Hilbers, M. Cihak et al. The analysis of the natural resource role in the macroeconomic dynamics of the financial system through banking activities in the stock market is covered in publications by: J. Bloom, A. Demirguc-Kunt, M. Quaintin, R. Levine, E. Fama, E.H. Hansen, R. J. Shiller. The methodological basis for the regulation of the market relationship, in general, and in the natural resource sector, in particular, has been developed by the representatives of the Keynesian concept and, to a considerable extent, by the followers of the opponent direction - monetarism. Keynes' ideas are developed in studies by G. Hicks, F. Fabozzi, F. Modigliani and R. Skidelsky. The theoretical substantiation of monetary and credit regulation of use of natural resources is covered in works by the proponents of the monetary theory: M. Friedman, K. Brunner, R. Lucas, F. Kydland, E. Prescott and J. Tobin.

Various aspects of providing security of activities of the bank as a key donor of sustainable use of natural resources, conservation of biodiversity are studied by domestic scientists: V. G. Alkema, A. I. Baranovskiy, V. K. Gizhevskiy, V. I. Hrushko, I. A. Hubareva, N. N. Yermoshenko, A. A. Yepifanov, S. A. Yerokhin, A. I. Zubok, V. V. Kovalenok, Ya. S. Koval, O. N. Kolodizev, O. S. Kirichenko, E. A. Kirichenko, V. I. Mishchenok, V. O. Lesik, N. S. Prokopenko, G. M. Ryzhakova, V. N. Lych, A. I. Shkuratov, A. A. Obikhod, E. V. Bondarenko et al. However, the analysis of their works has shown insufficient addressing the matters of forming an efficient model of the provision, with financial resources, of the system of use of 
natural resources and conservation of biodiversity, including applicability of best world practices in economic realities of Ukraine. At present, the scientific and expert community conducts an active revaluation of the financial system, in general, and banking activities in the stock market, in particular, in developing crisis and coronavirus crisis phenomena in the natural resource sector having an impact on the slowdown of the paces of growth of the world and national economy. In the context of rapidly transforming business models of the agents (institutional environment) of the financial sector, acting - the agents - as donors for the natural resource environment, the necessity to study deeper theoretical and methodological concepts of providing security for banking activities in the stock market arises, in which, in particular, the accumulation of monetary fund's takes place, required - the monetary funds - for developing sustainable use of natural resources, ecological balance and conservation of biodiversity in the context of Ukraine.

The purpose of this work is to discover and substantiate possible mechanisms for providing security for the financial system, in general and the bank (both commercial and state one) functioning in the stock market, in particular, not entering into a financial, economic and social confrontation with their specific function - provision of financing for sustainable use of natural resources and conservation of biodiversity within the framework of the global ecological initiative.

In the furtherance of the specified goal, the following main tasks have been set and solved:

1) to study the essence of activities of the bank and banking sector in theoretical coordinates of the financial globalistics and ecological initiative;

2) to determine the impact of the concept of sustainability of use of natural resources on ontology, gnosiology and genesis of evolutionization of methodical aspects of providing security of bank activities in the stock market;

3) to study the features of the monitoring of the financial stability of the bank and security of its activities in the stock market as a financial donor of sustainable use of natural resources and conservation of biodiversity.

A theoretical basis for the study have been fundamental and applied works of domestic and foreign scientists devoted to the matters of financial and economic security of the functioning of the "bank - banking system - 
stock market" triad, the economy of use of natural resources, in particular, the matters of conservation of biodiversity. For this purpose, the following methods have been used: of comparative analysis and synthesis, grouping of actual data and sample observations.

The above said tasks have made it possible to build a logic scheme of presenting material, central to which - a scheme - is security of the bank activities in the stock market as a kinematic condition attached to accelerations of particular bodies in the system of sustainable use of natural resources and conservation of biodiversity, while considering the institutional environment of the financial system as a whole of activities of the bank in the stock market has made it possible to tie, from a new previously unexplored perspective, with a financial thread, which mass determines the level of its security and sustainability of the functioning, the systems of financial provision of reproduction of the natural raw material base within the framework of the global ecological initiative.

\section{Essence of activities of the bank and banking sector in theoretical coordinates of the financial globalistics and ecological initiative}

Scientific views on the importance of ensuring the security of bank operations and the banking sector (BS) in financial and economic coordinates, and the arguments that are used in this case differ, are considered. Thus, there is an opinion that for any truly sovereign state, the issues of ensuring the stability of the national banking sector are of strategic importance and always relevant, forming the concept of the "economic security of the state" [7]. Other researchers note that the growth of the dynamism of social development is accompanied by an acceleration of the emergence of global economic crises, their growth in scale, and their migration to the financial sector, in particular, the banking sector. Therefore, ensuring the safety of bank operations and the banking sector is a major factor not only in the national but also in the international economy. Since the security of banks is an essential component of financial security, it is the state of the banking sector that determines the level of financial security of the state [24].

In our opinion, the importance of maintaining the security of the bank operations and banking sector in the financial and economic coordinates of the national economy has to do with the following: 
- banking security is considered too narrowly in the scientific literature, legal acts and law enforcement practice (mainly as security of an individual bank), while commercial banks do not function autonomously, since integration and globalization processes, the system of interbank settlements, and modern information technologies do affect their activities by increasing existing and causing new risks that cannot be minimized only by the efforts of the security service of a particular banking institution;

- global and local banking crises, low financial stability and security of the banking sector are among the main threats to the national security of any country;

- the banking sector is a mesoeconomic component of the national economy, and therefore has well-pronounced sectoral and territorial aspects of functioning, an important component of the development and strengthening of the market foundations of the country's economy [25-26; 52; 59].

In addition to the above, the importance of ensuring the security of the bank operations and the banking sector in the financial and economic coordinates of the national economy is also due to the fact that the financially stable banking sector has sufficient funds to solve the problems of ensuring information, personnel and physical security of individual banks and the banking sector as a whole. Finally, the financial and economic component is the result of all aspects of the banking sector, and its state is determined by the effectiveness of measures in all its supporting subsystems, so in the future study we will identify the concept of "security of the bank operations and the banking sector" with its financial and economic components.

In all developed countries, the establishment of systems to ensure the protection of public savings is recognized as a necessary and important element of an effective mechanism for maintaining the financial security and stability of the banking sector. However, it should be noted that the bank resource insurance system, even if it is properly organized, can only cope with a limited number of simultaneous bankruptcies, and it should not be expected that it will be able to cope with a systemic banking crisis on its own. Three approaches should be used for a comprehensive understanding, analysis and assessment of the security of the bank operations and the banking sector in the financial and economic coordinates of the national economy (Figure 1.1). 
Approaches to comprehensive analysis and assessment of security of bank and banking sector activity in financial and economic coordinates of national economy

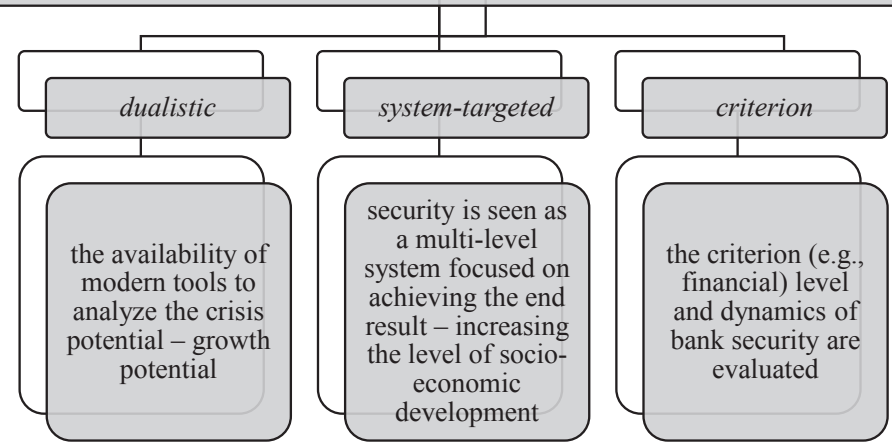

Figure 1.1. Approaches to comprehensive analysis and assessment of the security of the bank operations and banking sector in financial and economic coordinates of the national economy $[5 ; 33 ; 49]$

However, there are conceptual drawbacks in the scientific support for establishment of a security system for bank operations and the banking sector. In particular, there are no systemic theoretical and methodological approaches, well-established terminology, a scientifically based concept of ensuring the security of bank operations and the banking sector, a comprehensive analysis of challenges and threats to the security of bank operations and the banking sector as a whole, as well as its supporting subsystems.

The security of the bank operations and the banking sector can be studied from different viewpoints: legal and social, from the standpoint of economics, organization, technology, psychology, information, and others. However, the most important type of security of the bank operations and the banking sector is its economic and financial resilience, since it expresses the fundamental interests of people, business entities, society, and the state, and, therefore, largely determines the nature and direction of their actions.

The emphasis on the security of the country's monetary policy or the security of individual banking institutions is characteristic of the coverage of banking security issues in the special literature. 
Approaches to determining the essence of the security of the bank operations and the banking sector in the financial and economic coordinates of the national economy differ and have heterogeneous interpretations and approaches (Table 1.1). However, although the multi-aspect definition given of Table 1.1 expands the characteristics of the spectrum of security components of the bank operations and the banking sector, it still fails to provide a comprehensive picture of its essence.

Table 1.1

\section{Approaches to determining the essence of the security of bank operations and the banking sector in the financial and economic coordinates of the national economy}

\begin{tabular}{|c|l|}
\hline $\begin{array}{c}\text { Characteristics } \\
\text { of interpretation }\end{array}$ & \multicolumn{1}{c|}{\begin{tabular}{c}
\multicolumn{1}{c}{$\begin{array}{c}\text { Definition of the essence } \\
\text { of the concepts in question }\end{array}$} \\
\hline
\end{tabular}} \\
$\begin{array}{l}\text { Banking security is a state of sustainable life, which } \\
\text { ensures the implementation of the main interests } \\
\text { and priority goals of banks, protection from external } \\
\text { and internal destabilizing factors, regardless of the } \\
\text { conditions of their functioning. The main criterion for } \\
\text { the effectiveness of banking security is the stability of } \\
\text { the financial and economic condition of the bank. }\end{array}$ \\
$\begin{array}{l}\text { Banking security is a stable, financially consistent } \\
\text { state of the national banking system, which allows } \\
\text { for continuous implementation (as well as rapid } \\
\text { recovery from the negative impact of unforeseen } \\
\text { circumstances) by its participants of banking } \\
\text { operations and transactions, regardless of existing or } \\
\text { potential threats (risks). } \\
\text { The safety of the banking system in the financial- } \\
\text { economic coordinates of the national economy } \\
\text { considered as a state of existing law and relevant } \\
\text { security institutions, which reflects the level of } \\
\text { protection of the state financial and credit relations } \\
\text { between subjects of banking operations and } \\
\text { guarantee stable functioning of the banking system; } \\
\text { provides full implementation and protection of vital } \\
\text { financial and economic interests of the state, society } \\
\text { and the individual; excludes or limits the maximum } \\
\text { destructive effects of external and internal threats, } \\
\text { the imperfections of foreign trade, business, and } \\
\text { domestic trade activities }\end{array}$ \\
\hline
\end{tabular}


(End of Table 1.1)

\begin{tabular}{|c|c|}
\hline $\begin{array}{c}\text { Characteristics } \\
\text { of interpretation }\end{array}$ & $\begin{array}{l}\text { Definition of the essence } \\
\text { of the concepts in question }\end{array}$ \\
\hline $\begin{array}{l}\text { Possibility of further } \\
\text { development. } \\
\text { As a function of the state }\end{array}$ & $\begin{array}{l}\text { Banking security is not only the basis of viability } \\
\text { and the possibility of further development of the } \\
\text { banking services market, but also the creation of } \\
\text { a conflict-free external and internal environment. } \\
\text { The security of the banking system is associated } \\
\text { not only with such positive development, which } \\
\text { increases the volume of banking activity, but also } \\
\text { rationalizes the money turnover, i.e., provides } \\
\text { non-inflationary development, improves payment } \\
\text { discipline, introduces new financial products and } \\
\text { services, and improves their quality. Banking } \\
\text { security in the financial and economic coordinates } \\
\text { of the national economy should be considered as an } \\
\text { integral function of the state, its strategic direction, } \\
\text { which is embodied in the legal form and allows } \\
\text { minimizing economic (financial) losses, and in } \\
\text { some cases - preserving economic sovereignty and } \\
\text { even statehood itself. At the same time, ensuring the } \\
\text { stability of the national banking system is a strategic } \\
\text { component of banking security }\end{array}$ \\
\hline $\begin{array}{l}\text { Regulation of economic } \\
\text { standards, mandatory } \\
\text { economic regulations, and } \\
\text { requirements. } \\
\text { Exercising management } \\
\text { functions by the NBU, } \\
\text { government agencies, and } \\
\text { commercial banks in banking } \\
\text { operations and transactions. } \\
\text { Set of technical regulations } \\
\text { and requirements }\end{array}$ & $\begin{array}{l}\text { The security of bank operations and the banking } \\
\text { sector in the financial and economic coordinates of } \\
\text { the national economy includes three components: } \\
\text { 1) financial and legal, which is manifested through } \\
\text { the regulation of economic standards of banks, } \\
\text { mandatory economic regulations and requirements } \\
\text { for maintaining reserves (funds); } \\
\text { 2) administrative and legal - management functions } \\
\text { of the Central Bank, government bodies, and } \\
\text { banks in the implementation of banking operations } \\
\text { and transactions (including business continuity } \\
\text { and corporate governance, including personnel } \\
\text { management); } \\
\text { 3) information and legal as a set of technical } \\
\text { regulations and requirements that ensure the } \\
\text { protection of information and banking systems } \\
\text { themselves from unlawful interference and other } \\
\text { threats (risks) }\end{array}$ \\
\hline
\end{tabular}

Source: compiled by the author based on $[5 ; 26 ; 46-47 ; 50]$ 
When clarifying the essence of the security of the bank operations and the banking sector, individual researchers $[5 ; 8 ; 11 ; 17]$ try to link together the current legislation, security institutions, relations between banking entities, and the financial and economic interests of economic agents.

Therefore, the security of the bank operations and the banking sector is interpreted as a certain state; the possibility of further development; the function of the state; regulation of economic standards, mandatory economic regulations and requirements; activities of the NBU, government agencies, and commercial banks with regard to management functions while implementing banking operations and transactions; a set of technical regulations and requirements.

Scientists say that the financial and legal component of security of the bank operations and the banking sector characterizes the financial stability of the banking system. The financial stability of the bank operations and the banking sector is understood as a state, in which it, having the necessary liquidity reserve and developed infrastructure support, even in the conditions of the global financial crisis, will be able to withstand the shock situation at the expense of its own resources, without creating a threat to investment, and savings, and suspending (slowing down, complicating) other activities (operations, transactions) of banking organizations [20;29].

However, in our opinion, it is not correct to talk along with the stability of the aggregate of commercial banks and the stability of the NBU, since the latter should not be affected by any negative factors a priori.

Approaches to determining the essence of the economic security of the bank operations and the banking sector are also ambiguous (Table 1.2). As seen from the table, the economic security of bank operations and the banking sector is interpreted by scientists as a certain state characterized by ensuring the financial stability of the banking sector or banks; preventing threats and eliminating losses; the ability of government institutions and the banking sector as a whole to ensure the sustainable development of banking business and effective performance of economic functions by banks.

At the same time, there is no well-established definition in the economic literature of the essence of the security of the bank operations and the banking sector in the financial and economic coordinates of the national economy. Instead, researchers focus mainly on the concepts inherent in the banking micro-level. 


\section{Approaches to defining the essence of economic security of bank and the banking sector}

\begin{tabular}{|c|c|}
\hline $\begin{array}{c}\text { Specifics of } \\
\text { determination }\end{array}$ & Definition of the essence of the concepts in question \\
\hline System & $\begin{array}{l}\text { According to the system approach, the economic security of the } \\
\text { bank and the banking sector is a complex concept, the elements of } \\
\text { which must be presented as a system. A comprehensive approach } \\
\text { to assessing the security of the bank and the banking sector } \\
\text { involves meeting the following requirements: assess, on the one } \\
\text { hand, the possibility of countering banking crises, and on the other - } \\
\text { the possibility of development, expansion of activities; assess the } \\
\text { security of the banking system, projecting its development on } \\
\text { the country's economy; determine the vector orientation, which } \\
\text { indicates the main development guidelines taking into account the } \\
\text { versatility and dynamics of the "banking security" concept; allow } \\
\text { regular monitoring of the security of the banking system using a } \\
\text { system of indicators }\end{array}$ \\
\hline State & $\begin{array}{l}\text { Economic security of the bank and the banking sector is a dynamic } \\
\text { state, in which it is: legally and technically capable of performing } \\
\text { and actually performs its functions; ensures sustainable protection } \\
\text { of vital socioeconomic interests of citizens, business entities, } \\
\text { society and the state from the impact of internal and external } \\
\text { threats; has the necessary potential for both quantitative and } \\
\text { qualitative growth and mechanisms for realizing this potential }\end{array}$ \\
\hline $\begin{array}{l}\text { Ensuring the } \\
\text { state }\end{array}$ & $\begin{array}{l}\text { Economic security of the bank and the banking sector means } \\
\text { ensuring the best use of its resources in order to prevent threats } \\
\text { to commercial banks and create conditions for stable, efficient } \\
\text { operation and profit maximization. The level of economic security of } \\
\text { banking activity is determined by the degree of prevention of threats } \\
\text { and elimination of losses from the negative impact on the banking } \\
\text { system caused by departments and services of commercial banks. } \\
\text { The economic security of the banking sector is a state, in which } \\
\text { its financial stability or reputation cannot be undermined by } \\
\text { the purposeful actions of a certain group of individuals and } \\
\text { organizations or by the financial situation within and outside the } \\
\text { banking sector. } \\
\text { The economic security of the banking sector is a component of } \\
\text { the country's financial security, a state where banks cannot lose } \\
\text { financial stability and business reputation as a result of targeted } \\
\text { actions of a certain group of individuals or organizations both } \\
\text { inside and outside the state, as well as-as a result of negative } \\
\text { macroeconomic and political factors }\end{array}$ \\
\hline
\end{tabular}


(End of Table 1.2)

\begin{tabular}{|c|c|}
\hline $\begin{array}{c}\text { Specifics of } \\
\text { determination }\end{array}$ & Definition of the essence of the concepts in question \\
\hline $\begin{array}{l}\text { The ability of } \\
\text { government } \\
\text { institutions and } \\
\text { the banking } \\
\text { system to ensure } \\
\text { the sustainable } \\
\text { development } \\
\text { of the banking } \\
\text { business and } \\
\text { the effective } \\
\text { performance } \\
\text { of economic } \\
\text { functions by } \\
\text { banks }\end{array}$ & $\begin{array}{l}\text { The economic security of the banking sector in general and a } \\
\text { specific bank, in particular, is the ability of government institutions } \\
\text { (regulatory bodies, the banking community and top management } \\
\text { of banks) and the banking sector as a whole to ensure sustainable } \\
\text { development of the banking business and effective implementation } \\
\text { by banks of their economic functions, and implement (protect or } \\
\text { strengthen) national economic interests in relation to the processes, } \\
\text { events or actions that may endanger or interfere with these interests } \\
\text { at the national and international financial markets }\end{array}$ \\
\hline
\end{tabular}

Source: compiled by the author based on [17; 22-23; 31; 41; 56]

Thus, according to A. I. Baranovskyi, the financial security of a commercial bank is [7]:

a set of conditions, under which actions or circumstances that are potentially dangerous to the financial condition of a commercial bank are prevented or reduced to such a level that they are not capable of causing harm to the bank, preserving and reproducing its property and infrastructure, and preventing the bank from achieving its statutory goals;

the state of protection of the commercial bank's financial interests, its financial resilience, and the environment, in which it operates.

In our view, these characteristics of the financial security of the commercial bank, of course, given the synergies, possible manifestations of the "contagion" effect inherent in the functioning of the banking sector of the national economy, can be used to provide a comprehensive definition of financial security of the latter.

T. Bolhar gives an essential characteristic of the concept of "financial security of banks" as a state of banking institutions, which is characterized by balance and resistance to external and internal threats, its ability to achieve its goals and generate sufficient financial resources to ensure sustainable development [53]. In her opinion, the basis of the financial security system of banks is three subsystems: 1) financial diagnostics, 
2) financial levers and methods for ensuring financial security; 3) control and analysis of results.

M. Yermoshenko defines the financial component of the economic security of banking as a set of measures to achieve the maximum possible solvency and stability of a commercial Bank, the liquidity of its balance sheet, an effective capital structure and the most profitable areas of its investments, as obtained by clear strategic and tactical planning, analysis and prevention of financial threats. Its essence is to provide organizational and managerial, regulatory, technical and preventive measures that guarantee quality protection of the Bank's rights and interests, growth of the authorized capital, increasing the liquidity of assets, ensuring the repayment of loans, and preservation of financial and material assets [24].

Generally, we can agree with this point of view. However, the financial security of banking activities, even if these measures are ideal, cannot be provided properly as in this case, the extremely necessary measures of a purely economic and financial nature are not taken into account.

In our opinion, it is necessary to distinguish such types of security of the bank operations and the banking sector in the financial and economic coordinates of the national economy (Table 1.3).

Table 1.3

\section{Classification of types of the bank and banking sector security} in the financial and economic coordinates of the national economy

\begin{tabular}{|l|l|}
\hline \multicolumn{1}{|c|}{ Classification of features } & \multicolumn{1}{c|}{ Varieties } \\
\hline Goals & Strategic, tactical \\
\hline Static character & Functioning, development \\
\hline Form of manifestation & Internal, external \\
\hline The resource-functional approach & $\begin{array}{l}\text { Resource-creating component of the banking } \\
\text { sector functioning, deposit, credit, currency, } \\
\text { inflation, investment, debt }\end{array}$ \\
\hline State of the banking sector & $\begin{array}{l}\text { Security in the pre-crisis period, security during } \\
\text { the crisis, security in the post-crisis period }\end{array}$ \\
\hline Sufficiency level & $\begin{array}{l}\text { Sufficient, insufficient, acceptable, necessary, } \\
\text { boundary (threshold), excessive }\end{array}$ \\
\hline Reality & Real, imaginary \\
\hline Security status & Actual, expected, potential \\
\hline Level of achievement & Basic, transitional, advanced \\
\hline
\end{tabular}

Source: compiled by the author based on [5; 47; 56] 
The significance of this classification lies in the fact that such differentiation of the types of security of the Bank's activities and the banking sector makes it possible to identify patterns and certain specifics of their formation, functioning and development more clearly and can be used to determine specific directions for the development of the system of their provision and compliance.

Since the banking sector is a mesoeconomic component of the national economy, and therefore has clearly defined sectoral and territorial aspects of operation, its financial security is interrelated and interlinked with the financial security of the state as a whole, as well as the financial security of commercial banks, their clients and counterparties.

The state influences the activities of banks and the banking sector of the national economy by implementing monetary policy, whereas its safety is conditional upon the level and pace of development of individual commercial banks and their entirety, as well as socioeconomic development of the regions and the state as a whole.

At the same time, the financial security of commercial banks is although necessary but not a sufficient condition to ensure the safety of banking activities and the banking sector in the financial-economic coordinates of the national economy. Since the financial security of some commercial banks can determine the level of financial security, regulators must have a parity of influence on all of them without exception, otherwise, the financial security of some will co-exist with the huge risks of others.

In our view, the security of the bank operations and the banking sector in the financial and economic coordinates of the national economy, firstly, is not limited only to ensuring the safety of the sector as such, and, secondly, it is wrong to distill it down to the preservation and effective use of the existing potential without taking into account the need for comprehensive progressive development of this very important component of the national economy.

Therefore, in our opinion, the security of bank operations and the banking sector in the financial-economic coordinates of the national economy as a whole is the financial security of both commercial banks and their customers and counterparties, professional financial market participants, the regulator of the banking market and the state, as the functioning of the banking sector is associated with banking risks, which include not only the 
risk of financial loss of the banking institutions, but also the risks associated with the activities of economic agents. In addition, the above losses may result in the risk of failure to achieve the banking regulator's goals and failure or substandard performance of legislatively fixed functions, growth of shadowing of the national economy and unproductive outflow of capital abroad, and thus have a negative impact on the financial security of the state as a whole.

The essence of the security of bank operations and the banking sector in the financial and economic coordinates of the national economy, in our opinion, is:

- a set of economic, social and legal relations that determine the financial condition of the banking sector, which ensures the financial sovereignty of the state, the stability of the banking sector to challenges, external and internal threats, and the effective use of its financial potential, preventing the deterioration of the financial condition of all participants in the banking services market;

- the ability and readiness of the banking sector in time and space to protect the financial interests of clients, counterparties, owners and employees of commercial banks, professional participants in financial markets, the banking services market regulator and the state as a whole from challenges, external and internal threats;

- public good, the usefulness of which is determined by the need of economic agents to preserve their savings, high-quality cash and settlement services and lending in the required volumes on acceptable terms and providing quality supplementary banking services;

- conditions, under which actions or circumstances that threaten the financial condition of commercial banks and the banking sector as a whole (taking into account the synergistic effect, the possibility of the "contagion" effect inherent in its operation) are not allowed or minimized;

- a set of socioeconomic, financial, regulatory, organizational and managerial, technical and technological, educational, educational and regulatory measures aimed at protecting the banking sector from external and internal challenges and threats and ensuring its financial stability and sustainable development.

From the above, we can conclude that the security of the bank operations and the banking sector in the financial and economic coordinates of the 
national economy is a system that is characterized from an essential and structural point of view and is interpreted from different positions as a set of relations, ability, and readiness, the public good, a set of conditions and a set of measures.

An important point in determining the theoretical and methodological foundations of the subject in question is the allocation of the security area for bank activities and banking sector in the financial-economic coordinates of the national economy as a combination of optimal parameters, financial capacity, financial resilience, reliability, business and investment attractiveness, effectiveness of operation, which indicates the possibility to minimize, prevent and eliminate threats and challenges of the external and internal environment.

A very important aspect of ensuring the security of the bank operations and the banking sector in the financial and economic coordinates of the national economy is the unambiguous definition of its purpose, objects, and subjects of such security, as well as the principles of the organization (Figure 1.2).

The financially secure banking sector of the national economy is the guarantor of the financial security of the state, since, depending on its qualitative state, it can be a factor in both accelerating and slowing down the economic growth.

It is wrong to limit the security system of both banks and the banking sector solely to a set of legal, organizational, technical and special measures while excluding the most important aspect of security - the economic one, since it is the effective development of a bank's potential and compliance with economic and legal standards that allow avoiding threats to its security $[3 ; 19 ; 22 ; 57]$.

At the same time, the vector orientation of building a multistage security system of the banking sector should be from the lower level to the higher.

The system of the bank and the banking sector security in the financialeconomic coordinates of the national economy should be based on the development of concepts, strategies and tactics of its security requirements for such a system and principles of the organization, its goals and objectives, objects and subjects, mechanisms of support (methods, tools, incentives and levers) and support subsystems (regulatory, organizational, methodological, financial, personnel, technological, analytical, monitoring and control). 


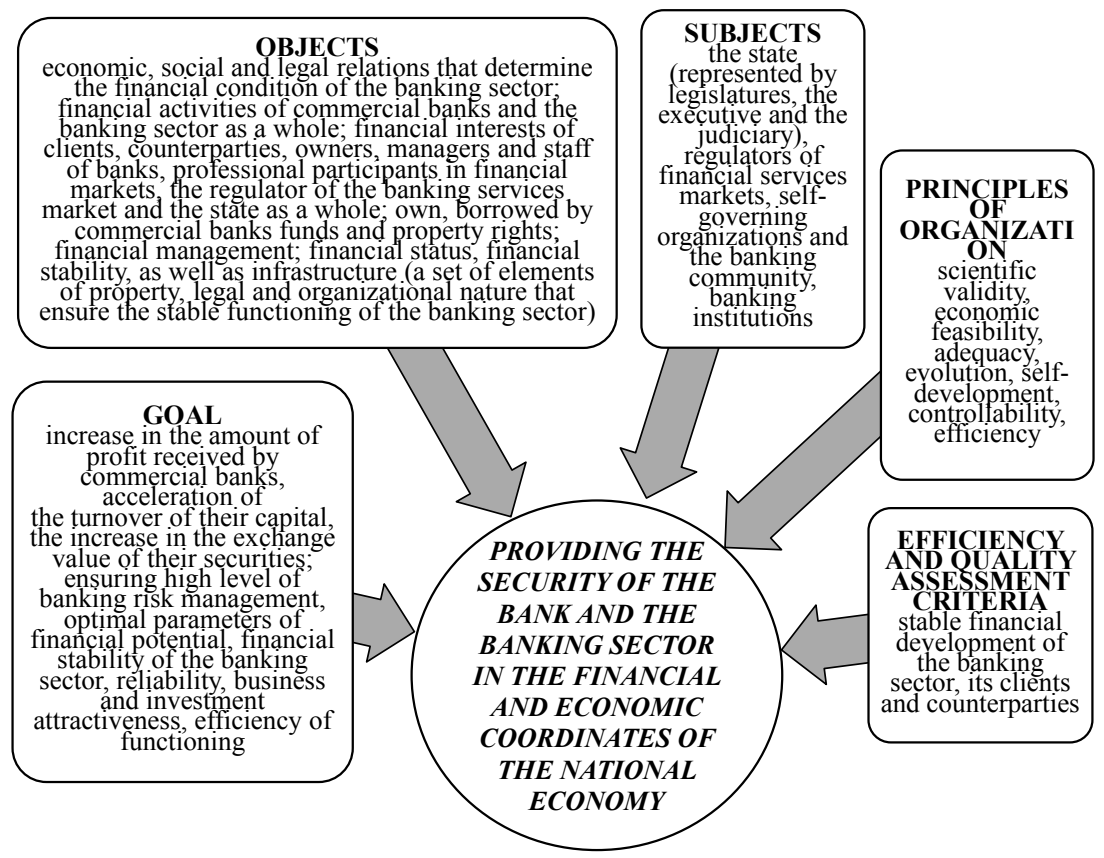

Figure 1.2. Elements of the bank and the banking sector security system in financial and economic coordinates of the national economy $[18 ; 20-21 ; 25 ; 30 ; 54]$

First of all, the system of ensuring the security of the bank operations and the banking sector in the financial and economic coordinates of the national economy must be dynamic and able to adapt to the changing operating conditions.

Thus, the security system of the bank operations and banking sector in the financial-economic coordinates of the national economy is a set of dynamic, capable of adapting to changing conditions of functioning and transparent, interconnected and interdependent, elements, based on sound scientific concepts (definition of requirements for such a system, its goals and objectives, objects and subjects, the principles of the organization), the strategy and tactics of security of the banking sector, financial diagnostics of the latter, incentives and levers, methods and tools, monitoring and analysis of the results of its software and its underlying subsystems. 


\section{Impact of the concept of sustainability of use of natural resources on ontology, gnosiology and genesis of evolutionization of methodical aspects of providing security of activities of the bank in the stock market}

In the context of the financial crisis and the aggravation of political instability in Ukraine, it is possible to observe a trend of deterioration in the performance indicators (profitability, solvency and financial condition in general) of domestic banks on the stock market. It is the quality of the developed security measures at the level of a commercial bank (CB) as a key unit of the banking sector that determines its financial condition and the vector of development of the banking sector in the strategic perspective. However, the development of a scientifically-based mechanism for ensuring the security of the Bank's activities on the stock market (SBASM) is preceded by an analysis of scientific approaches to determining the essence of the term "banking security", and then "stock market" as one of the most effective mechanisms for attracting and distributing investment resources, the value of which is increasing.

In security science, the main term is the concept of "security" as it encompasses all the terms that are varieties of security depending on the scope of application, as well as the basis for their definition. Processing and generalization of economic literature $[4 ; 12 ; 26-27]$ have allowed us to determine and schematically recreate the relationship between the banking security and the economic security of the state (Figure 2.1). Figure 2.1 shows that financial security is the key component. Domestic researchers interpret financial security as a state of protection of values and (or) interests from external and internal threats. However, in our opinion, for the further proper substantive content of the concept of bank financial security, one should take into account four approaches to the interpretation of the concept "security": static (status of security), active (system of measures aimed at creating a safe environment), passive (standards and parameters that determine the security level), apophatic (no threats ) [21;32].

Thus, A. I. Baranovskyi believes that the financial security of the state is the status of the financial, currency, monetary, budgetary, banking, settlement, tax, customs and tariff, investment, stock and pricing system, characterized by stability and balance of external and internal negative influences, the ability to withstand external financial expansion while 


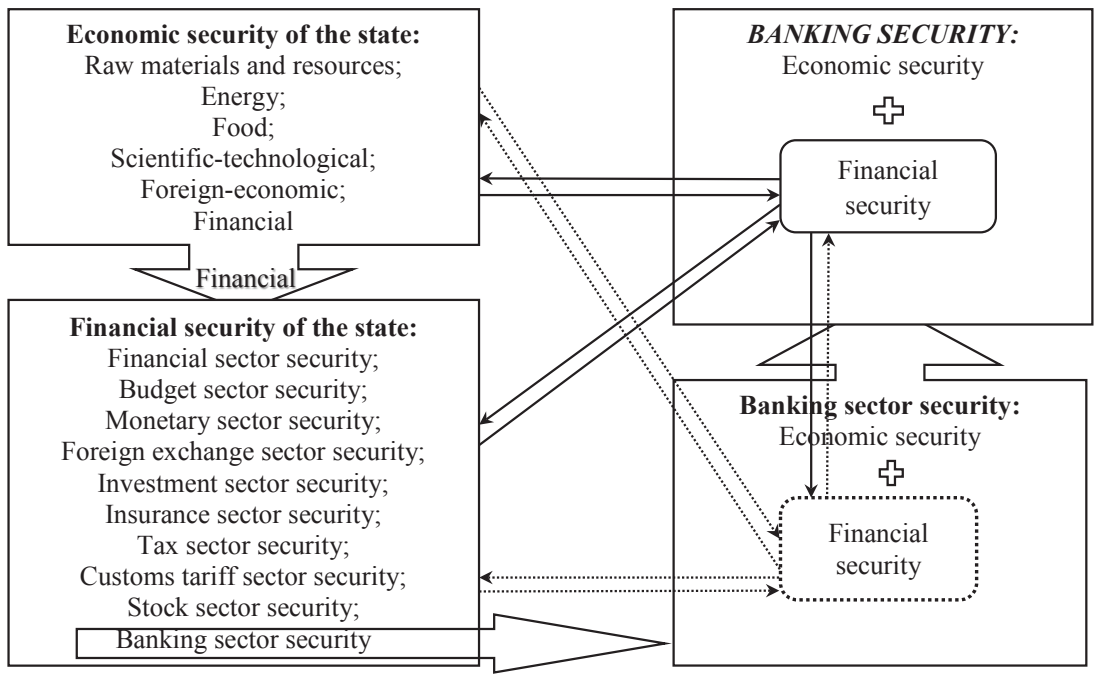

\section{Figure 2.1. Relationship between the banking security and the financial security of the state}

Source: compiled by the author based on $[6 ; 15 ; 20 ; 34 ; 40]$

ensuring financial resilience (stability), economic growth and effective functioning of the national economic system, and we agree with such a statement [5]. In our opinion, carving out financial safety of the Bank's activities, as a component of financial security of the state is absolutely justified as, firstly, the banking institutions possess the levers to directly influence the efficiency of investment, financial, production and other sectors of the national economy, and secondly, the efficiency of banking sector directly affects the amount of money, which in turn directly affects the functioning of the real economy. So, we can say that the state of the banking sector significantly affects the level of financial security of the state.

M. I. Zubok, S. M. Yaremenko [26] emphasize that "the bank security is such a state in which conditions for ensuring sustainable life are created, while the main interests and priority goals of the bank are realized, under the conditions of protection from external and internal destabilizing factors, regardless of the operating conditions". 
It is important to note that the security of an individual $\mathrm{CB}$ directly affects the security of the banking sector, since CBs are financial and credit centers that influence the state of the national economy when attracting and placing temporarily available funds. At the same time, structural changes in the activity of an individual $\mathrm{CB}$, distrust on the part of the population, and mass withdrawal of deposits cause negative system-wide consequences. In addition, it is important to realize that it is impossible to achieve the proper level of security of an individual CB without achieving the corresponding indicator at the system-wide level. In our opinion, it is necessary, on the one hand, to emphasize that there is a logical relationship between financial and economic activity of the $\mathrm{CB}$, and, on the other hand, to underline the importance of considering the bank financial security as a necessary and independent part of the effective operation of the CB.

In the context of the study of bank financial security phenomenon, the following approaches can be identified to interpret the content of this concept: protective, resource-functional, competitive, and systemic.

From the viewpoint the interpretation of A. I. Baranovskyi [7] of the protective approach as the protection of the financial interests of the $\mathrm{CB}$, its financial sustainability and the environment, in which operates, and also set the conditions, under which potentially hazardous to the financial condition $\mathrm{CB}$ actions or circumstances alerted or reduced to a level, at which they are not able to harm the established order of functioning of the $\mathrm{CB}$, preservation and reproduction of its property and infrastructure and prevent the achievement of the statutory objectives of the $\mathrm{CB}$, deserves attention.

Financial security of the bank from the position of the resourcefunctional approach M. M. Yermoshenko [24] is considered as a state of the most effective use of corporate resources of the Bank, which is displayed using the best values of indicators of profitability, quality, management and use of fixed and current assets of CB, the structure of its capital, the norm of dividend payments on securities $\mathrm{CB}$ as well as market value of its securities as a synthetic indicator of the current financial state of the $\mathrm{CB}$ and the prospects for its technological and financial development.

V. R. Vovk [14] notes that the principal goal of the bank's financial security is to ensure the competitiveness of both the individual CB and the banking system as a whole in the banking services market and to prevent 
the possibility of receiving losses or losing part of the profit due to the implementation of internal and external threats.

The essence of the system approach is that when deciding on ensuring the financial security of the Bank's activities, operation $\mathrm{CB}$, the activity of employees, and the impact of both internal and external threats are seen as a dynamic system in the complex of its relations from the point of view of sustainability and self-development.

On the basis of generalization of the views of scientists, identifying the main advantages and disadvantages of approaches to revelation of the essence of "financial safety of bank activity" as the main derivative of the concept of "security activities", the bank can claim that a protective approach is the most scientifically balanced and reasonable, often used in modern conditions of functioning of the bank, according to which the financial security of banking activities is defined, firstly, as a state of the bank, in which its financial stability and its financial interests are protected from the destructive factors, both external and internal environment; secondly, the bank exhibits such a behavior that would allow it to function effectively and to achieve its statutory objectives in the face of continuous internal and external threats [7; 18; 42].

In Ukraine, commercial banks are currently the main financial institutions that form the infrastructure of the stock market (Figure 2.2). Acting as investors in the stock market, banks conduct a significant amount of investment operations, and as active participants have a significant impact on the market.

Specifics of banking activities and the status of their security in the domestic stock market is mainly contingent on the economic situation in the country, stable banking system, and development of stock market, historical and transformational realities of economic transformation in Ukraine. The CBs in the stock market act as direct investors, issuers, its infrastructure participants (traders, custodians, registrars) and as consultants or intermediaries.

The legislation of Ukraine defines that the following types of professional activities can be carried out on the stock market: securities trading activities; asset management activities for institutional investors; depository activities; and activities for organizing trade on the stock market [45] (Figure 2.3).

Intermediary operations of banks on the stock market include:

I. In the field of professional activity in securities trading - brokerage, underwriting and securities management (professional activity in the 


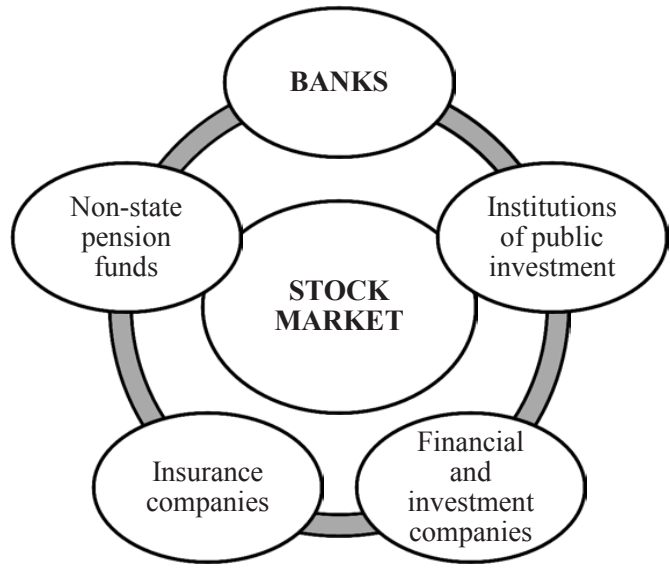

Figure 2.2. The place of banks in the structure of institutional investors in the stock market $[9 ; 14 ; 55]$

stock market - activity in securities trading consists of transactions that involve payment of securities against their delivery to the new owner. Professional activity in securities trading is carried out by banks as well. Securities trading activities are divided into the following types: brokerage; dealer activities; underwriting; securities management. 1. Brokerage is the conclusion of civil law contracts by a securities-trading bank (in particular, commission agreements, orders) regarding securities on its own behalf or on behalf of another person and at the expense of another person. In addition, the bank may act as a guarantor of fulfillment of obligations to third parties under the contracts concluded on behalf of the client subject to appropriate remuneration for this. 2. Underwriting is the placement (subscription, sale) of securities by the bank on behalf of, and at the expense of its client being their issuer. According to the scientists [28;40;48], the world experts predict a significant activation of the global and domestic stock and bond markets in the coming years, because credit resources for enterprises have become expensive and difficult to access, so they will look for alternative sources of capital. Banks have the opportunity to develop and capture their share of the underwriting services market in this direction [37]. 3. Securities management is carried out by the bank trading in securities on its own behalf for a fee for 


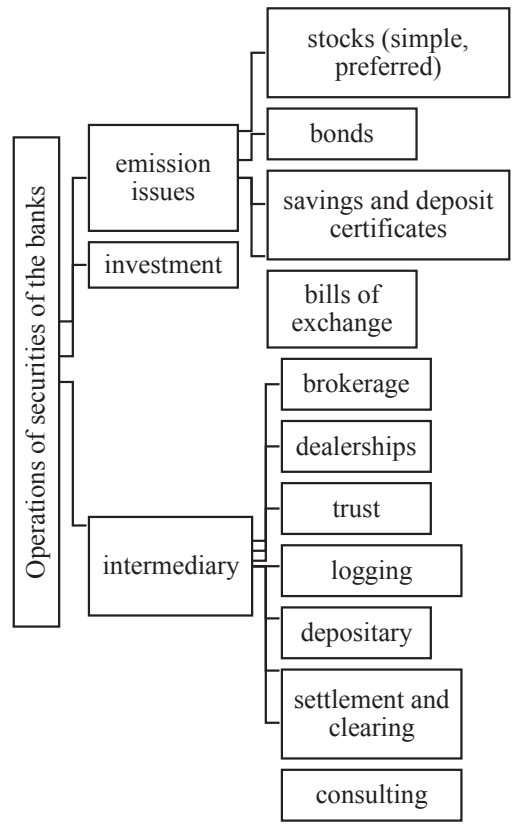

2
A share is a registered security that certifies property rights of the owner (shareholder) relating to joint-stock companies, including the right to participate in the profit of joint-stock companies in the form of dividends and the right to receive part of the property of jointstock companies in the event of liquidation, the right to manage a joint-stock company as well as non-property rights envisaged by the Civil Code of Ukraine and the law that regulates establishment, operation and termination of joint-stock companies, and legislation on collective investment institutions. Each type of shares entitles the holder to various rights.

Bond is a security that certifies its deposit by the first owner of money, determines the relationship of the loan between the bondholder and the issuer, confirms the issuer's obligation to repay the nominal value the bondholder provided by the terms of the bond placement period and to pay the bond yield unless otherwise provided by the terms of the placement.

Promissory note is a security that certifies an unconditional monetary obligation of the promiser its order to a third party to pay a certain amount to the owner of the note (the holder) after the maturity date. Promissory notes can be promissory or transfer notes.

Savings (deposit) certificate is a security that confirms the amount of the deposit made to the Bank and the rights of the depositor (certificate holder) to receive the deposit amount and the interest set by the certificate from the issuing bank after the expiration of the specified period. Savings (deposit) certificates are placed for a certain period of time (at the interest provided by the terms of their placement). Savings (deposit) certificates can be registered or bearer certificates

Figure 2.3. Bank operations with securities $[37 ; 45]$

a certain period of time on the basis of an agreement on the management of securities transferred to it and funds intended for investment in securities, as well as securities and funds received in the course of this management that belong to the client by right of ownership, in its interests or in the interests of third parties identified by it. In addition, banks can perform trust operations. Trust operations with securities shall be understood as the activity of a commercial bank as a Trustee of its clients to manage securities on its own behalf and at its own discretion, with the obligation to preserve 
and increase the client's capital for a certain percentage of the client's asset growth. For trust operations, a separate trust department is organized in a commercial bank, which is usually a separate division, with its own funds and balance sheet. In General, it should be noted that when performing any type of professional trading in securities on the stock market, banks are obliged to act in the interests of their clients, to coordinate the possible transaction risks with them, first of all, to perform operations with securities under contracts and one-time orders of clients, to notify the client of the bank's personal interest, which may become an obstacle to fulfilling the obligations assumed. In addition to these types of securities trading, banks provide investment banking services, which cover a full range of services related to the organization of mergers, acquisitions, and restructuring of enterprises, search for strategic investors and issuers of securities. A bank as a broker or dealer can perform the functions of a market maker, i.e., buying or selling securities of its issuing client, maintaining their liquidity and influencing the market value);

II. In the area of professional depository activity - custodianship and maintaining registers of owners of registered securities (depository activity is the provision of services for storing securities regardless of the form of issue, opening and maintaining accounts in securities, servicing operations on these accounts (including clearing and settlements under agreements on securities) and servicing operations of the issuer with respect to securities issued by it. The custodianship as a type of a depository activity consists of performing the following core functions: securities safekeeping (a non-documentary form of issue); servicing the circulation of securities on securities accounts; servicing the Issuer's operations with respect to the securities issued by it [1]. Securities safekeeping involves performing the following functions by the custodian bank: acceptance, storage and transportation of securities certificates and certificates of immobilization of securities; issuance of certificates of securities held by the custodian; verification of securities certificates for authenticity and availability of all required details; inventory of securities certificates and certificates of immobilization of securities, and so on. While servicing the circulation of securities on securities accounts, the custodian bank performs administrative (opening and closing securities accounts, making changes to account profiles, etc.), accounting (maintaining securities accounts, reflecting transactions 
with securities that result in a change in the number of securities on accounts, etc.) and informational (issuing statements and certificates on the status of the securities account and transactions with securities) operations. The activity of maintaining registers of registered securities owners as a type of Depository activity provides for recording and storing information about the owners of registered securities (the documentary form of the securities issue) and about transactions resulting in the need to make changes to the register of registered securities owners for a certain period of time. The share register contains the following information about:

- issuer;

- registrar;

- issue of securities for which the register is attached;

- holders of securities registered in the registry system;

- nominee holders (depository or custodian of securities to whom these securities are transferred on behalf of and in the interests of registered holders for transactions in the National Depository system).

The Registrar opens a personal account for the owner of registered securities. The Registrar opens two types of accounts for the registered holders: the issuer account and the issuer's personal account. In addition, the registrar issues at the request of the securities owner or its representative, as well as the nominee holder, an extract from the share register which are of two types: an account statement and an extract on transactions on the personal account for a certain period. At the same time, to organize general meetings of shareholders or accrual of income from securities, the registrar prepares lists of registered owners and performs other information and registration functions on the basis of a written request from the issuer);

III. Depositary member (depositary is a legal entity engaged exclusively in depository activities and may carry out clearing and settlement of agreements on securities. Banks can only be members of the depository, because it is established in the form of a public joint-stock company, the members of which are at least ten custodians, in particular, the share of one member in the authorized capital of the depository may not exceed $25 \%$. The following depositories have been established in Ukraine: National Depository of Ukraine and the All-Ukrainian Securities Depository. Clients of the Depository are custodians who have entered into depository agreements with it; issuers regarding accounts in securities of their 
own issues; other depositories with which a correspondent relationship agreement has been concluded).

Active operations of banks to place their own and borrowed funds in securities are associated with the risk of incurring losses in the event of a deterioration in the financial condition of securities issuers, a decrease in the market price of securities due to changes in interest rates on the market, changes in the investment policy of banks. In order to minimize this risk, banks are required to create a special reserve for compensation of possible losses from operations with securities.

As a rule, in our country, banks invest in corporate (stocks, bonds) and government (bonds, treasury bills, treasury bonds) securities. The most important group of financial investment instruments today are stock levers, the purpose of which is to stabilize bank income by securing cash receipts: domestic government bonds (DGB), external government bonds (EGB), corporate bonds, shares, savings certificates, mortgage securities, REPO operations, underwriting, and others.

However, the imperfection of the national stock market, namely, its low capitalization and liquidity, the lack of internal financial resources for investment, insufficient legislative regulation of pricing, the number of investment-attractive and liquid financial instruments is limited, and the lack of licenses to carry out exchange activities restricts the ability of banks to carry out investment activities. From the point of view of security, this state of development of the stock market renders it impossible to diversify the bank active operations, expand the sphere of competitive influence of the $\mathrm{CB}$ and the client base by participating in the securities portfolio of enterprises. On the other hand, the stock exchange's failure to perform its key function of accumulating financial resources and placing them in the real sector of the economy creates an inflated demand for bank credit resources and directly affects the loan price. Thus, in the absence of competition, banks provide loans at inflated prices, while their income increases, that is, opportunities for ensuring financial security are expanded. Given that banks operate in various sectors of the financial market, ensuring their security should be carried out regardless of the type of banking operations and block all possible ways to implement threats. Moreover, the more complex the situation, the more active the security forces should be. Based on this, bank security departments develop appropriate measures to protect all operations 
carried out by banks without exception. At the same time, considerable attention is paid to ensuring the safety of bank operations on the stock market, especially operations with securities.

Operations with securities take second place (after loans) in terms of risk. A significant part of bank clients and banks themselves suffer losses, lose opportunities for effective investment of their funds and obtaining corporate rights of promising enterprises as a result of these operations. It is through the actions of stock market scammers that bank clients can obtain securities of prospectless or non-existent issuers, and in some cases, by investing funds, they cannot get any rights at all.

Therefore, the following steps may be considered as main directions of ensuring the bank security in the stock market: 1) amending the legislation in order to improve the mechanisms for protecting investors and shareholders and developing stock market instruments; 2) creating conditions for the development of an organized securities market, which would allow to get a real picture of demand for securities, the volume of their sales; 3) developing investment infrastructure and solving the problem of low investor confidence in the Ukrainian stock market; 4) improving hedging mechanisms, which will allow banks to reduce the risks of issuing activities; 5) creating a Central Depository, which will help depositories to establish relations with depository institutions of other countries [37].

\section{Features of the monitoring of the financial stability of the bank and security of its activities in the stock market as a financial donor of sustainable use of natural resources and conservation of biodiversity}

Monitoring in modern conditions is, as a method of studying and analyzing socioeconomic situations, a way of implementing organized systematic monitoring of the progress and qualitative changes in the development of the country as a whole or its components (e.g., regions), their impact on specific research objects, determining critical points of growth and preventing or eliminating the latter, and developing mechanisms for further development of society, its individual elements on this basis. Therefore, monitoring is a universal tool for strategic management and can be used in relation to various areas of public activity, which ultimately determines the object of observation, goals and list of tasks. 
In the works of researchers $[36 ; 44]$, who consider the problems of creating monitoring systems in various areas of public activity, the need to justify monitoring systems as an independent scientific direction, as the main functional subsystem (as part of the system) for managing economic objects, is emphasized.

Monitoring as an economic category in [51] is defined as continuous monitoring of economic objects, analysis of their activities as an integral part of management, and in accordance with [38], as a process that provides for dynamic tracking of the state and parameters of the system, as well as the generation of reports on changes that have occurred over the past period.

The variety of interpretations of the essence of the concept of "monitoring" is explained by the use of this tool in various areas of public activity. Since banking is a rather complex and multifaceted area in the economic system of relations, the use of monitoring in the banking sector, in particular, in the context of ensuring the financial stability of the banking system and the security of its activities on the stock market, is necessary and relevant in today's economic and political imbalances.

The specifics of monitoring in the banking sector are reflected in the concept of "bank monitoring".

According to the researcher [35], bank monitoring should be understood as a complex information system that includes monitoring the state of the banking sector, evaluating its results and predicting the future development of the country's banking system and individual commercial banks. A similar definition of bank monitoring is provided by P. V. Pryimak [44], who describes bank monitoring as a system of measures to monitor the activities of commercial banks constantly, collect and systematize data on their financial condition to assess the current state of affairs in the banking sector and forecast its development in the future.

A. A. Kirichenko and V. I. Mishchenko supplement the definitions and interpret "bank monitoring" as a system of constant monitoring of all controlled limits and standards, determining the size and reasons for deviations of actual indicators from the normative ones, the reasons for these deviations, and making managerial decisions [4].

According to the author [20], monitoring should be considered from a functional and organizational point of view. For the first approach, monitoring the stability of the banking system should be understood as 
an information system that covers observations (the main characteristic of monitoring is its continuity) on the level of stability of the banking system, analysis, assessment and forecasting of stability for the long term. From an organizational point of view, monitoring the stability of the banking system is considered as a system. Therefore, like any system, monitoring should cover certain elements that interact and are influenced by internal and external factors. At the same time, the main purpose of monitoring the stability of the banking system, as indicated by the researcher [20], is to prevent crisis phenomena.

Analyzing the definition of bank monitoring as given by other scientists, we can conclude that this concept is closely related to management in a controlled object. Thus, the author [44] notes that monitoring of the banking system is a set of measures for monitoring, processing, analyzing, storing, forecasting, and improving the management of the banking system, aimed at determining the impact of the environment and reducing the likelihood of various types of risks.

According to the economic practitioner [51], monitoring of bank activities involves specially organized, systematic monitoring of the state of objects, phenomena, processes in order to assess, control or forecast them. The main field of the practical application of monitoring is the information service of the anti-crisis management process in system banks. Therefore, the system of monitoring of banking operations must fulfill the tasks for the collection and accumulation of information, which reflects the main indicators of the competitor banks, evaluation of the external environment of the banking institution, development trends of the banking system in general, analysis and forecast of indicators of financial stability of the systemic bank, evaluation of systemic risks, the safety of its activities on the stock market, the efficiency of the activities implemented within the framework of state regulation of banks and internal bank policies.

According to the researcher [29], monitoring of the stability of the banking sector involves analyzing the state of the national banking sector, financial sector, assessing the impact of the global banking environment thereon, and identifying positive or negative factors that will cause changes in the banking sector in the future.

The issues of monitoring the Bank's financial stability have also been discussed in the work of G. M. Azarenkova, I. V. Shkodina [1]. The authors 
note that the economic direction of monitoring the financial stability of the bank should reflect qualitative changes in the bank's development, and be a tool for comparing the bank functioning, both in terms of different time intervals and in terms of the selected system of indicators of banking operations. At the same time, the assessment of the bank financial stability should take into account not only the generalized dynamics of each of the selected indicators of banking operations but also their dynamics in accordance with each other.

From the authors' point of view [48; 50], the essence of monitoring the financial condition of banking institutions is to track changes in financial indicators and coefficients for the period under study - not only to confirm the stability of the analyzed bank but also to identify strengths and weaknesses, in order to act as a competitor simultaneously in the market of banking products and services.

The economic focus of monitoring the bank financial stability and the security of operations on the stock market should reflect qualitative changes in the bank development and be a means of comparing the Bank's performance, both in terms of different time intervals and in terms of the selected system of indicators [58].

Thus, the analysis of the considered definitions of the concept of "monitoring" in various fields of activity, in particular, in banking, allows us to note that there are no fundamental differences in the considered interpretations, they complement one another.

Summing up the study of the content of the monitoring features and problems of its implementation in the banking sector, the monitoring of financial stability of the banking system as a whole and the security of the bank operations in the stock market shall be understood as the process of continuous monitoring (the collection and accumulation of information), processing, and analysis of values of indicators of an estimation of financial stability at the macro and microeconomic levels in order to improve the validity of management decisions and forecasting the future development of the banking system, its dynamic movement in general and the security of the banking operations in the stock market [39]. Based on the presented definition of the concept, the principles of monitoring the financial stability of the banking system are defined (Figure 3.1). 


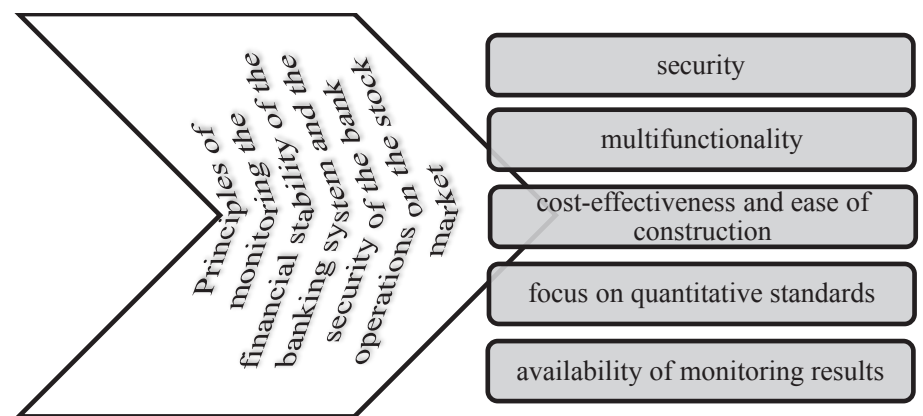

Figure 3.1. Principles of monitoring the financial stability of the banking system and security of the bank activity on the stock market [1-2]

Among the principles for monitoring the financial stability of the banking system and the security of the bank operations in the stock market presented in Figure 3.1, the key one is the continuity principle, which means that the collection, accumulation, processing, and analysis of information on assessing the stability of the banking system, as well as separately, must be carried out on an ongoing basis.

The next is the principle of multifunctionality, which takes into account the complexity and versatility of banking activities and provides for monitoring of various components of the assessment of financial stability.

At the same time, one should bear in mind that monitoring should be based on the principle of cost-effectiveness and ease of construction, that is, the number of indicators for assessing financial stability should be limited to obtain timely and high-quality information.

In turn, the principle of focusing on quantitative standards provides for increasing the effectiveness of financial stability monitoring, provided that it is possible to quantify all areas, which ensures that the conclusions and management actions that are formed on the basis of its results are unambiguous.

Finally, there is the principle of accessibility of monitoring results, which provides for the availability of conclusions and monitoring results for all interested users of information about the banking system and the activities of a particular bank. 
Analysis of the above interpretations of monitoring in various fields also allowed us to conclude that most scientists reveal the features of its implementation through the main stages, which are the assessment, control, and forecast of the state of objects. At the same time, depending on the monitoring objects, individual economic scientists provide separate proposals for improving this process. Thus, the approach of A. V. Laznia [38] to specify the stages of monitoring indicators of the financial stability of the banking system and the security of the bank operations on the stock market is quite interesting. The author distinguishes the following stages of implementation: definition of the current values of the indicators; determination of the integral indicator of financial stability; the variance of the integral indicator in comparison with previous periods; identification of the influence of individual indicators on the change of the integral indicator; estimation of the scale of impact and level of development of the indicator, a negative bound for the integral indicator of financial stability; assessment of the possible consequences and causes of adverse changes in indicators; forecasting the values of the indicators and dependent-integral indicator; determining the level of fluctuation of the forecast values of the indicators and dependent-integral indicator; the future values of the indicators. V. R. Vovk [13] draws attention to the fact that in the process of forming the monitoring information base, it is necessary to clearly understand the directions and relationship of information flows describing the state of the object of research, which, in turn, will allow to develop a system that will provide monitoring subjects with accurate and operational primary information about the state of the object monitored. M. M. Rybalkin [47] notes that the main goal of monitoring the stability of the banking system and bank security on the stock market is to prevent crisis phenomena. Therefore, in the monitoring process, it is mandatory to oversee the banking system constantly for identifying factors that affect or may affect its stability, determining the relationship and interdependence of these factors, and take appropriate and timely corrective measures. In [24] the attention is focused on the fact that monitoring of the financial stability of the banking system should include both an integrated analysis of the financial stability of banks, and provide for analysis and assessment of banking risks.

Stages of monitoring of financial stability of the banking system and bank security in the stock market take into account the features of formation 
of the system to ensure and provide for: [39]: 1st stage - formation of the analytical framework of monitoring the financial stability of the banking system and banking security in the stock market; 2nd stage - comparison of the results of integral estimation of financial stability at the macro and micro levels in the current period according to preliminary data; 3rd stage - the mapping of private indicators for assessing financial stability at the macro and micro levels with the thresholds in the current period; 4th stage - identifying the causes of changes indicators to assess the financial stability of the banking system and banking security in the stock market; 5th stage - determining ways of ensuring the financial stability of the banking system and banking security in the stock market; 6th stage - to identify the prospects for changing the level of financial stability of the banking system and individual banks in the stock market. The content and results of each of the stages of monitoring of financial stability of the banking system and banking security in the stock market (Table 3.1) are determined based on the monitoring objects, which in this case are the level of financial stability of the banking system (estimated from the position of the properties of emergence) and the level of financial stability of banks in the stock market.

Table 3.1

Sequence and results of implementing of the proposed stages of monitoring the financial and investment stability of the banking system and security of the bank activity on the stock market

\begin{tabular}{|c|c|c|}
\hline Tasks & Methods & Results \\
\hline \multicolumn{3}{|c|}{$\begin{array}{l}\text { I. Forming an analytical framework for monitoring the financial stability } \\
\text { of the banking system and the security of the bank activity on the stock market }\end{array}$} \\
\hline $\begin{array}{l}\text { I. 1. Calculation of } \\
\text { indicators for assessing } \\
\text { the financial stability of } \\
\text { the banking system and } \\
\text { the bank security from the } \\
\text { position of the emergency } \\
\text { (macro level) }\end{array}$ & \multirow{2}{*}{$\begin{array}{l}\text { Analysis of the } \\
\text { coefficients. } \\
\text { Entropy method. } \\
\text { The "Golden section" } \\
\text { method }\end{array}$} & \multirow{2}{*}{$\begin{array}{l}\text { Indicators for assessing the } \\
\text { intensity of investment and } \\
\text { financial interaction in the stock } \\
\text { market, the effectiveness of the } \\
\text { banking system's functions, } \\
\text { structural changes and financial } \\
\text { imbalances, and the activities } \\
\text { of system banks were obtained. } \\
\text { The level of the banking system } \\
\text { and the bank security in the } \\
\text { stock market was determined }\end{array}$} \\
\hline $\begin{array}{l}\text { I. 2. Determining the } \\
\text { quantitative and qualitative } \\
\text { levels of the banking } \\
\text { system and the bank } \\
\text { security }\end{array}$ & & \\
\hline
\end{tabular}




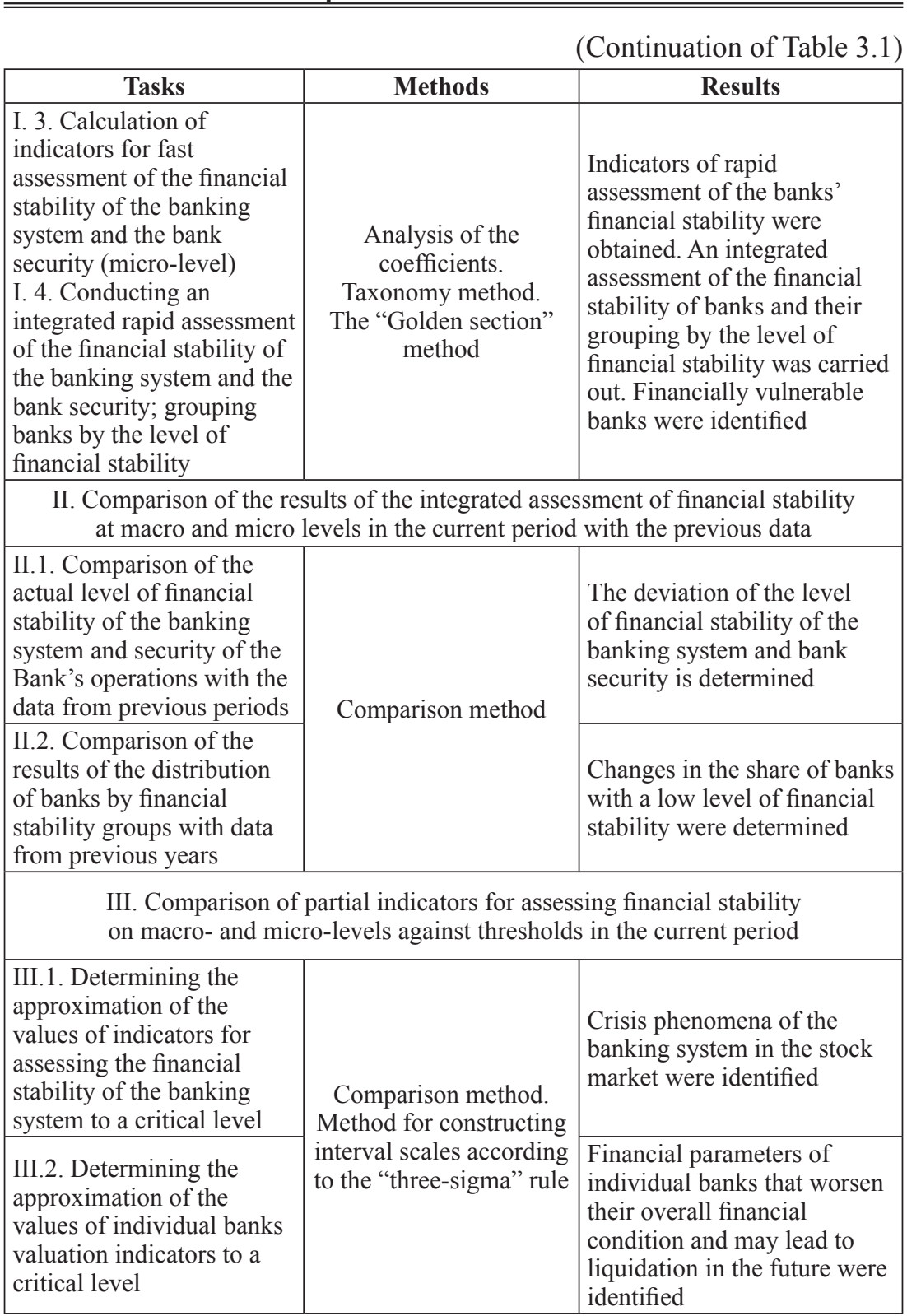


(End of table 3.1)

\begin{tabular}{|c|c|c|}
\hline Tasks & Methods & Results \\
\hline \multicolumn{3}{|c|}{$\begin{array}{l}\text { IV. Determining the reasons for changes in the indicators for assessing } \\
\text { the financial stability of the banking system and the security of the bank activities } \\
\text { on the stock market }\end{array}$} \\
\hline $\begin{array}{l}\text { IV.1. Analysis of cause- } \\
\text { and-effect relationships } \\
\text { between groups of } \\
\text { indicators of financial } \\
\text { stability of the banking } \\
\text { system and security of the } \\
\text { bank activities }\end{array}$ & $\begin{array}{l}\text { Logical generalization } \\
\text { method. } \\
\text { Canonical correlation } \\
\text { method }\end{array}$ & $\begin{array}{l}\text { The list of factors that caused } \\
\text { the negative change of } \\
\text { certain groups of indicators } \\
\text { for assessing the financial } \\
\text { stability of the banking } \\
\text { system and the security of the } \\
\text { Bank's activities on the stock } \\
\text { market was clarified }\end{array}$ \\
\hline $\begin{array}{l}\text { IV.2. Analysis of the impact } \\
\text { of banking regulation } \\
\text { instruments on the overall } \\
\text { level of financial stability } \\
\text { of the banking system } \\
\text { and security of the bank } \\
\text { operations }\end{array}$ & $\begin{array}{l}\text { Multidimensional } \\
\text { regression analysis }\end{array}$ & $\begin{array}{l}\text { The most effective tools of } \\
\text { banking regulation were } \\
\text { identified }\end{array}$ \\
\hline \multicolumn{3}{|c|}{$\begin{array}{l}\text { V. Justification of directions for ensuring financial stability of the banking system } \\
\text { and security of the bank activity on the stock market }\end{array}$} \\
\hline \multicolumn{3}{|c|}{$\begin{array}{l}\text { VI. Identification of prospects for changing the level of financial stability } \\
\text { of the banking system and individual banks in the stock market }\end{array}$} \\
\hline $\begin{array}{l}\text { VI.1. Analysis of changes } \\
\text { in parameters that } \\
\text { characterize banking } \\
\text { regulation tools in the } \\
\text { stock market }\end{array}$ & $\begin{array}{l}\text { Calculation of resilience } \\
\text { coefficients }\end{array}$ & $\begin{array}{l}\text { The prospects for changing } \\
\text { the overall level of financial } \\
\text { stability of the banking system } \\
\text { and the security of the Bank's } \\
\text { activities were identified taking } \\
\text { into account its sensitivity to } \\
\text { the effectiveness of banking } \\
\text { regulation instruments on the } \\
\text { stock market }\end{array}$ \\
\hline $\begin{array}{l}\text { VI.2. Analysis of trends in } \\
\text { approximating banks based } \\
\text { on their level of financial } \\
\text { stability }\end{array}$ & $\begin{array}{l}\text { The method of } \\
\text { convergent-divergent } \\
\text { analysis }\end{array}$ & $\begin{array}{l}\text { The forecast levels of } \\
\text { financial and investment } \\
\text { stability of banks in the stock } \\
\text { market were determined. } \\
\text { A list of banks that were } \\
\text { forecast to have a low level } \\
\text { of financial and investment } \\
\text { stability in the stock market } \\
\text { has been formed }\end{array}$ \\
\hline
\end{tabular}

Source: compiled by the author based on $[16 ; 35-36 ; 38-39 ; 44 ; 51]$ 
It should be noted that the use of separate scientific methods as provided by stages 3 to 6 (in particular, the method of constructing interval scales using the three-sigma rule, the method of canonical correlations, multidimensional regression analysis, and elasticity coefficients), is provided only at the first iteration of the corresponding continuous process. This is due to the fact that the collection of information for monitoring, as well as for evaluating financial stability and comparing the results of the assessment, although they are the most time-consuming stages, they are reflected in almost all approaches to the relevant issue. Therefore, it is considered appropriate to elaborate only on those stages of monitoring the financial stability of the banking system and the banking security on the stock market, which allows improving the relevant process and increasing the effectiveness of its implementation.

Thus, the need to implement the third stage of monitoring the financial stability of the banking system and the banking security on the stock market, which involves comparing private indicators for assessing financial stability at the macro and micro levels with thresholds in the current period, is explained by the fact that financial stability and crisis are diametrically opposite states of the system. Therefore, identifying and overcoming crisis phenomena and processes in the banking system and in the financial activities of individual banks on the stock market is a necessary prerequisite for ensuring the financial stability of the country's banking system. The corresponding conclusions, which are reflected in various models for predicting systemic banking crises, are presented in the works of both foreign and domestic economic scientists [33; 39].

B. Eichengrin and A. Rose [64] include a set of macroeconomic indicators in the system of indicators of the banking crisis that describe the dynamics of the national economy, exchange rate regime, financial structure of the country, and the specifics of supervising institutions for monitoring and regulating banking activities. A similar version of the system of criteria for the banking crisis is presented in the work of J. Caprio and D. Klingebil [63], who suggest using the volume of transactions in the country's financial market and the degree of volatility of GDP growth rates and import and export growth rates as the main indicators of banking crises.

In [60] an approach to early detection of banking crises is presented, which is based on a system of simple indicators (GDP and its components, 
inflation, interest rates, and money supply indices). An alternative option proposed by K. Borio and M. Dremann [62] includes signals determined by synchronous limit values for real estate prices, securities exchange rates, and credit spreads.

$\mathrm{K}$. Borio and F. Low [61] note that a large-scale banking crisis usually occurs as a result of the deterioration of the financial stability of the banking system and manifests itself in periods of low and stable inflation.

T. Vasilieva and O. Afanasieva [10] determine the level of bankruptcy risk of the individual banking institutions taking into account factors that affect the stability of their activities. L. Perekhrest [43] emphasizes the need to create a combined system of indicators of the banking crisis, which should include both macroeconomic and microeconomic indicators. In her opinion, the proposed system of indicators will allow to monitor trends in the banking sector and the bank operations in the stock market and detect signs of deterioration in time.

V. V. Kovalenko [29-30] proposes to use the proportion of nonperforming assets to total assets $<10 \%$, the cost of restoring the banking system $<2 \%$ of GDP, the level of nationalization of the banking system $<10 \%$, monitoring for the return of funds to depositors - systemic in nature, the rate of index change of the official hryvnia to U.S. dollar in accordance with the figures of the previous period $\geq 6 \%$ [29-30] as indicators of the banking system crisis. However, it should be noted that the threshold values for the presented indicators are not determined empirically, but are generalized on the basis of existing both foreign and domestic experience.

It should be noted that some of the Russian scientists also focus on the need to identify factors that can lead to the destabilization of the banking system. However, the difference between the corresponding stage of financial stability monitoring is the use of reasonable threshold (limit) values of its evaluation indicators. It is proposed to scale the individual indicators for assessing the financial stability of the banking system and the financial stability of banks; to compare the calculated values of indicators with high, medium and low levels; to use the scale interval that corresponds to the low level of each of the analyzed indicators as a basis for determining their threshold values.

At the 4th stage of monitoring the financial stability of the banking system and the security of the bank operations on the stock market, it is 
expected to determine the reasons for changes in the indicators for assessing the financial stability of the banking system. A feature of the implementation of this stage is to take into account the cause-and-effect relationships between groups of indicators of financial stability of the banking system and the impact of banking regulation tools on its overall level. The results of the implementation of these sub-steps are the clarification of the list of factors that caused the negative change of certain groups of indicators for assessing the financial stability of the banking system in the current year in comparison with the previous period; determination of the most effective tools for ensuring the financial stability of the banking regulation system. According to the logic of monitoring the financial stability of the banking system and the security of the bank operations on the stock market, the 5 th stage summarizes the results of the previous stages and forms general recommendations for ensuring the financial stability of the banking system. The results of determining the prospects for changing the level of financial stability of the banking system and levels of financial stability of banks (6th stage of monitoring) also help to specify further actions to ensure the financial stability of the banking system and to avoid distortions in the banking sector, which may be due to deterioration in the performance of the most financially vulnerable banks. In other words, the analysis of changes in the parameters of bank regulation to destroy that, which is the most sensitive level of financial stability of the banking system (sensitivity is determined using the calculated coefficients of elasticity), and identify convergence and divergence trends in the approach of banks according to their level of financial stability allow us to develop predictions about the development of the banking system and banks in the short term; justify corrective actions for implementation of banking regulation; to determine the banks, for which a low level of financial stability and the necessary increased control over their activities is forecast.

\section{Conclusions}

In addition to socio-economic, political and cultural relations, the mankind is united, in the first turn, by being in a closed space - on the planet Earth. A space, which, in accordance with the law of relativity, becomes increasingly narrower with developing new technologies and means of communication. The nature does not recognize state and administrative 
borders and the efforts of only one or several states are not able to prevent an ecological crisis and give tangible positive results. Understanding these processes dictates the trends in the environment, modernization of active financing of its reproduction, provision of the ecological balance and biodiversity.

Theoretical and methodological approaches based on the principles of the global ecological initiative, socio-oriented activities of acceptors of natural and land scape resources, laid as the basis for the architectonics of financing of reproduction of the natural and raw material base of the western system, are hardly applicable to solving domestic tasks of sustainable use of natural resources because the basis for them is formed by the ideas, first of all, of recreational use of depressed territories and only after that - of conservation of biodiversity, while the high-priority task of the Ukrainian system is an efficient building of a 4D model: "sustainable use of natural resources providing biodiversity - putting the territories out of depression - forming security of the functioning of the financial donor". In Ukrainian financial and economic realities colored by stagnation of the economy due to the COVID-19 coronavirus pandemic, by reducing in budget spending on building a system of sustainable use of natural resources, ecological balance and conservation of biodiversity, carrying out of land reform as well as low financial capability of united territorial communities bring a banking sector, among the variety of sources of financing, to a forefront, the institutional environment of which - the banking sector - is able, to a different efficiency extent, to accumulate monetary flows in the stock market additionally.

The bank and banking sector security is the financial security of a set of commercial banks, as well as their clients and counterparties, professional participants in financial markets, the banking services market regulator, and the state since the functioning of the banking sector is associated with banking risks, which include not only the risks of financial losses of banking institutions but also the risks that economic agents associated with their activities encounter.

The security of bank operations and banking sector in the financialeconomic coordinates of the national economy is a set of economic, social and legal relationships behind this financial condition of the banking sector, which will ensure financial sovereignty of the state, the stability of the banking sector to challenges of external and internal threats and effective 
use of its financial capacity, preventing deterioration of the financial condition of all participants of the banking services market; the ability and willingness of the banking sector in time and space to protect the financial interests of clients, contractors, owners, and employees of commercial banks, professional participants of the financial markets regulator of the banking market and the state as a whole.

The safety of operation of the bank and of the banking sector in the financial-economic coordinates of the national economy is determined by such factors as the prevailing development model of commercial banks; granularity of elements of the banking sector; opportunistic behavior of economic agents accepted; the monopoly of the banks on certain types of activities; loan culture; fund culture of raising money, financing methods; the features of the financial system in the country; the availability of banking services and the extent disintegration; the presence on the territory of the countries of transnational banks; the level of counteraction to laundering the "dirty" money; development of globalization processes, the level of financial literacy of existing/potential customers.

In Ukraine, banks are currently the main financial institutions that form the infrastructure of the stock market. Acting as investors in the stock market, banks conduct a significant amount of investment operations, and as active participants have a significant impact on the market.

Specifics of banking activities and the status of their security in the domestic stock market is mainly contingent on the economic situation in the country, stable banking system, and development of stock market, historical and transformational realities of economic transformation in Ukraine.

However, the imperfection of the national stock market, namely, its low capitalization and liquidity, the lack of internal financial resources for investment, insufficient legislative regulation of pricing, the number of investment-attractive and liquid financial instruments is limited, and the lack of licenses to carry out exchange activities restricts the ability of banks to carry out investment activities. From the point of view of security, this state of development of the stock market renders it impossible to diversify the bank active operations, expand the sphere of competitive influence of the $\mathrm{CB}$ and the client base by participating in the securities portfolio of enterprises. Based on this, bank security departments develop appropriate measures to protect all operations carried out by banks without exception. 
At the same time, considerable attention is paid to ensuring the safety of bank operations on the stock market, especially operations with securities.

According to the study of the essence of monitoring and its use in banking practice, it is determined that the monitoring of the financial stability of the banking system and security of the bank operations is a continuous process of observation (collection and accumulation of information), processing, and analysis of values of indicators of an estimation of financial stability at the macro and microeconomic levels in order to improve the validity of management decisions and forecasting the future development of the banking system, its dynamic movement and security activities of banks. The following stages of monitoring of financial stability of the banking system and security of the bank operations: formation of the analytical foundations of research (data collection and calculation of individual and consolidated indicators to assess the financial stability of the banking system and banks separately); a comparison of the actual results of the assessment with data from previous years; a comparison of the calculated values of partial indicators with critical (threshold) that signals the presence of the crisis; an analysis of the causes and consequences of the revealed deviations of the indicators; justification of the dominants to ensure the financial stability of the banking system, and security of the bank operations, identifying prospects for improvement and changes in the levels of financial investment in the stability of banks.

The theoretical and applied results obtained make possible to lay the groundwork for building a program platform (simulator) for the analysis of effects of made decisions in the regulation of the financial and natural resource system, such as limitation of the minimum price step, maximum application lifetime, transaction tax and other measures planned to be used by world financial regulators, inter alia, within the framework of the DoddFrank Act and the European MiFID II Directive.

\section{References:}

1. Azarenkova, Gh. M., \& Shkodina, I. V. (2017). Osnovni tendenciji rozvytku fondovogho rynku $\mathrm{v}$ postkryzovyj period [The main tendencies of stock market development in the post-crisis period]. Visnyk of the National Bank of Ukraine, no. 2, pp. 3-7.

2. Aljejnikova, N. M. (2016). Funkcionuvannja fondovogho rynku Ukrajiny v umovakh ekonomichnoji nestabiljnosti finansovogho seredovyshha [Functioning of 
the stock market of Ukraine in the conditions of economic instability of the financial environment]. Odesa National University Herald, vol. 4(46), pp. 144-149.

3. Aljkema, V. Gh., \& Kyrychenko, O. S. (2014). Upravlinnja zminamy v systemi ekonomichnoji bezpeky sub'jektiv ghospodarsjkoji dijaljnosti [Managing changes in the economic security of business entities]. Scientific Notes of "KROK" University, vol. 38, pp. 112-118.

4. Kyrychenka, O. A., \& Mishchchenka, V. I. (ed.) (2005). Bankivs'kyj menedzhment [Banking management]. Kyiv: Znannja. (in Ukrainian).

5. Baranovs'kyj, O. I. (2014). Filosofija bezpeky [Security philosophy]. Kyiv: UBS NBU. (in Ukrainian).

6. Baranovs'kyj, O. I. (2009). Finansovi kryzy: peredumovy, naslidky $i$ shchljaxy zapobihannja [Financial crises: prerequisites, consequences and ways of prevention]. Kyiv: KNTEU. (in Ukrainian).

7. Baranovsjkyj, O. (2014). Pryroda ekonomichnoji bezpeky komercijnogho banku [The nature of the economic security of a commercial bank]. Visnyk of the National Bank of Ukraine, no. 7, pp. 12-19.

8. Bjelohlazova, H. M., \& Krolyvec'ka, L. P. (2008). Bankivs'ka sprava [Banking]. Kyiv: SPb. (in Ukrainian).

9. Brus, S. I. (2011). Banky na fondovomu rynku Ukrajiny: zmina investycijnykh priorytetiv [Banks in the Ukrainian stock market: changing investment priorities]. Economy and Forecasting, no. 4, pp. 86-96.

10. Vasyljjeva, T. A., \& Afanasjjeva, O. B. (2013). Proghnozuvannja ryzyku vynyknennja kryzy v banku [Forecasting the risk of a crisis in the bank]. Herald of the Ukrainian Academy of Banking, no. 1(34), pp. 74-81.

11. Vitlins'kyj, V. V., \& Velykoivanenko, H. I. (2014). Ryzykolohija v ekonomici ta pidpryjemnyctv [Riskology in Economics and Entrepreneurship]. Kyiv: KNTEU. (in Ukrainian).

12. Reverchuk, S. K., Kovaljuk, O. M., Strel'byc'ka, I. M., \& Krupka, M. I. (2002). Vlada. Banky. Biznes: politekonomija vzajemodiji i rozvytku [Power. Banks. Business: political economy of interaction and development]. Kyiv: Atika. (in Ukrainian).

13. Vovk, V. R. (2015). Vzajemozv'jazok fondovogho rynku ta ekonomichnogho zrostannja [The relationship between the stock market and economic growth]. Visnyk of the Lviv University, no. 52, pp. 239-244.

14. Vovk, V. R. (2013). Osoblyvosti povedinky investora na fondovomu rynku [Features of investor behavior in the stock market]. Visnyk of the Lviv University, no. 50 , pp. 36-41.

15. Bohdan, T. P., Shcharov, O. M., \& Sl'ozko, O. O. (2017). Vplyv hlobal'nyx finansiv na valjutno-finansovu systemu Ukrajiny [Impact of global finance on the monetary and financial system of Ukraine]. Kyiv: DU "Instytut ekonomiky ta prohnozuvannja NAN Ukrajiny". (in Ukrainian).

16. Garyaga, L. O. (2007). Misce monitoryngu u bankivskij diyalnosti [Place of monitoring in banking]. The Problems of Economy, no. 5, pp. 153-165.

17. Hlushchchenko, V. V., Doroshchenko, H. O., \& Doroshchenko, N. O. (2014). Ekonomichna bezpeka finansovyx ustanov [Economic security of financial institutions]. Xarkiv: SHCHchedra sadyba pljus. (in Ukrainian) 
18. Grebenyuk, N. O. (2016). Finansova bezpeka bankiv: systema rozpiznannya zagroz ta usunennya ryzykiv [Financial security for banks: a system for identifying threats and eliminating risks]. Vestnik KhNU. Economic series, vol. 91, pp. 53-64.

19. Hubareva, I. O., \& Shtaier, O. M. (2013). Zabezpechennja upravlinnja ekonomichnoju bezpekoju banku [Ensuring the management of the bank's economic security] Xarkiv: INZHEK. (in Ukrainian).

20. Dovhan', ZH. M. (2012). Finansova stijkist' bankivs'koji systemy Ukrajiny [Financial stability of the banking system of Ukraine] (PhD Thesis), Sumy: State Higher Educational Institution "Ukrainian Academy of Banking of the National Bank of Ukraine".

21. Evseev, C. P. (2016). Sinergeticheskiy podkhod k otsenke bezopasnosti bankovskikh system [Synergetic approach to assessing the security of banking systems]. Information Processing Systems, vol. 4, pp. 90-103.

22. Zaxarov, O. I., Kyrychenko, O. A., Hrushchko, V. I., \& Jeroxin, S. A. (2010). Ekonomichna bezpeka bankivs'koji systemy v konteksti novoho kursu reform v Ukrajini 2010-2015 rokiv [Economic security of the banking system in the context of the new course of reforms in Ukraine 2010-2015]. Kyiv: Dorado-Print LLC. (in Ukrainian)

23. Varnalij, Z. S. (2009). Ekonomichna bezpeka [Economic security]. Kyiv: Znannja. (in Ukrainian)

24. Jermoshchenko, M. M., \& Horjacheva, K. S. (2010). Finansova skladova ekonomichnoji bezpeky: derzhava i pidpryjemstvo [Financial component of economic security: the state and the enterprise]. Kyiv: National Academy of Management. (in Ukrainian)

25. Zachosova, N. V. (2016). Formuvannya systemy ekonomichnoyi bezpeky finansovyx ustanov [Formation of system of economic security of financial institutions]. Cherkasy: PE Chabanenko Yu. A. (in Ukrainian)

26. Zubok, M. I., Yaremenko, C. M. (2019). Bezpeka bankivskoyi diyalnosti [Banking Security]. Kyiv: KNEU. (in Ukrainian)

27. Zubok, M. I. (2015). Globalizacijni vyklyky finansovij bezpeci [Globalization wikipedia financial safety]. Finance, accounting and audit, vol. 19, pp. 81-90.

28. Kloba, L. G. (2016). Finansova bezpeka ta ryzyky bankivskoyi investycijnoyi diyalnosti [Financial security and risks of banking investment activities]. Investytsiyi: praktyka ta dosvid (electronic journal), no. 12, pp. 6-12. Retrieved from: http://www.investplan.com.ua/pdf/12_2016/3.pdf (accessed 10 January 2020).

29. Kovalenko, V. V. (2017). Strategichne upravlinnya finansovoyu stijkistyu bankivskoyi systemy [Strategic management of financial stability of the banking system]. Sumy: FEU "UABS NBU". (in Ukrainian)

30. Kovalenko, V. V. (2013). Strukturni elementy j ocinyuvannya rivnya finansovoyi bezpeky bankivskoyi systemy [Structural elements and assessment of the financial security level of the banking system]. The Actual Problems of Regional Economy Development, vol. 9(1), pp. 191-199.

31. Koval', Ja. S. (2019). Vdoskonalennja informacijno-analitychnoji systemy ekonomichnoji bezpeky bankiv na derzhavnomu rivni [Improvement of the information-analytical system of economic security of banks at the state level]. Scientific Notes of "KROK" University, vol. 2(54), pp. 212-221. 
32. Koval', Ja. S. (2018). Derzhavne rehuljuvannja ekonomichnoju bezpekoju bankivs'kyx ustanov Ukrajiny [State regulation of economic security of Ukrainian banking institutions]. Scientific Notes of "KROK" University, vol. 4(52), pp. 176-190.

33. Kolodizjev, O. M., \& SHCHtajer, O. M. (2011). Formuvannja universal'noji systemy ocinky ekonomichnoji bezpeky banku [Formation of a universal system for assessing the bank's economic security]. The Problems of Economy, no. 2, pp. 67-75.

34. Cabinet of Ministers of Ukraine (2012). The concept of security of national security in financial spheres (Order, no. 589-p, August 15). Retrieved from: https://zakon.rada.gov.ua/laws/show/569-2012-\%D1\%80

35. Kotov, A. V. (2004). Monitoring bankovskoy infrastruktury [Banking Infrastructure Monitoring] Catalog of articles and study guides "JourClub" (electronic journal). Retrieved from: http://www.jourclub.ru/13/1260/1 (accessed 26 February 2020).

36. Kralich, V. R. Finansovyj monitorynh u zabezpechenni funkcionuvannja systemy ekonomichnoji bezpeky bankivs'kyx ustanov v Ukrajini [Financial monitoring in ensuring the functioning of the economic security of banking institutions in Ukraine] (PhD Thesis), Kiyv: State University of Banking.

37. Kuz'mins'kyj, V. Z., Ivanenko, T. V., \& Stojlovs'kyj, D. M. (2013). Dijal'nist' bankiv na rynku cinnyx paperiv Ukrajiny [Banks' activity in the securities market of Ukraine]. Scientific Notes of "KROK” University, vol. 33, pp. 107-117.

38. Laznja, A. V. (2014). Udoskonalennja systemy ocinjuvannja i monitorynhu finansovoji stabil'nosti bankivs'koji systemy Ukrajiny [Improvement of the system of assessment and monitoring of the financial stability of the banking system of Ukraine]. Economic Forum, no. 2, pp. 199-209.

39. Lesyk, V. O. (2015). Analiz problem rozvytku systemy monitorynhu finansovoji stabil'nosti vitchyznjanoho bankivs'koho sektoru ekonomiky [Analysis of the problems of development of the system of monitoring the financial stability of the domestic banking sector of the economy]. Bankivska sprava, no. 3(134), pp. 69-77.

40. Ljubkina ,O. (2014). Operaciji Central'noho banku na finansovomu rynku $\mathrm{v}$ umovax vyxodu $\mathrm{z}$ recesiji [Central Bank operations in the financial market in the face of recession]. Bulletin of Taras Shevchenko National University of Kyiv. Economics, vol. 1, pp. 57-61.

41. Mihus, I. P., \& Dudchenko, N. V. (2013). Transparentnist' banku jak skladova mexanizmu zabezpechennja joho ekonomichnoji bezpeky [Transparency of the bank as a component of the mechanism of ensuring its economic security]. Business Inform, no. 10, pp. 322-327.

42. Otenko, I. P., Mishchyn, O. Ju., \& Mishchyna, S. V. Orhanizacija ta upravlinnja finansovo-ekonomichnoju bezpekoju bankivs'kyx ustanov [Organization and management of financial and economic security of banking institutions]. Kharkiv: Simon Kuznets Kharkiv National University of Economics.

43. Perexrest, L. M., Perexrest, Ju. A., \& Jakovleva, A. A. (2012). Uperedzhennja finansovoji nestabil'nosti bankiv jak naprjam zmicnennja bankivs'koho sektoru ekonomiky [Prevention of financial instability of banks as a direction of strengthening of the banking sector of economy]. Collection of scientific papers of the National University of the State Tax Service of Ukraine, no. 1, pp. 330-336. 
44. Pryjmak, P. V. (2013). Monitorynh bankivs'koji systemy jak pidxid do upravlinnja jiji rozvytkom [Monitoring the banking system as an approach to managing its development]. Scientific Bulletin of UNFU, vol. 23.14, pp. 235-241.

45. Verkhovna Rada of Ukraine (2006). On securities and the stock market (the law of Ukraine, no. 3480-IV, February 23). Retrieved from: http://zakon2.rada.gov.ua/ laws/show/3480-15

46. Prokopenko, N. S., \& Vykljuk, M. I. (2014). Skladovi bezpeky bankivs'koji dijal'nosti [Components of banking security]. Scientific Bulletin of UNFU, vol. 24.1, pp. 302-308.

47. Rybalkin, H. H. (2006). Filosofiya bezopasnosti [Safety philosophy]. Moscow: MSTT. (in Russian)

48. Sl'ozko, O. O. (2014). Problemy stanovlennja finansovoho rynku krajin SND [Problems of the establishment of the financial market of the Krai SND]. Kiyv: LAT \& K. (in Ukrainian)

49. Stepanjuk, N. A. (2016). Analiz prychyn kryzovoji dynamiky ekonomiky Ukrajiny [Analysis of the causes of the crisis dynamics of the Ukrainian economy]. Global and National Problems of Economy (electronic journal), vol. 10. Retrieved from: http://global-national.in.ua/archive/10-2016/48.pdf (accessed 25 March 2020).

50. Strel'byc'ka, L. M., Strel'byc'kyj, M. P., \& Hizhevs'kyj, V. K. (2015). Bankivs'ke bezpekoznavstvo [Banking security]. Kiyv: Condor. (in Ukrainian)

51. Suhanjaka, M. V. (2012). Formuvannja systemy antykryzovoho upravlinnja systemnym bankom na osnovi stres-testuvannja z uraxuvannjam makroekonomichnyx pokaznykiv [Formation of system of crisis management of system bank on the basis of stress-testing taking into account macroeconomic indicators]. Herald of the Dnepropetrovsk National University, no. 10/1, T. 20, pp. 131-139.

52. Fedosov, V. M., Oparin, V. M., \& Pajentko, T. V. (2013). Innovaciji u finansovij sferi [Innovation in the financial sector]. Kiyv: National Economic University named after Vadym Hetman. (in Ukrainian)

53. Poberezhnyj, S. M., Plastun, O. L., \& Bolhar, T. M. (2015). Finansova bezpeka bankivs'koji dijal'nosti [Financial security of banking activities]. Sumy: State Higher Educational Institution "Ukrainian Academy of Banking of the National Bank of Ukraine". (in Ukrainian)

54. Vasyl'chyshchyn, O. B. (2017). Finansova bezpeka bankivs'koji systemy Ukrajiny: filosofs'ki determinant [Financial security of the Ukrainian banking system: philosophical determinants]. Ternopil: TNEU. (in Ukrainian)

55. SHCHapoval, M. S. (2017). Dominanty rozvytku fondovoho rynku v Ukrajini [Dominants of stock market development in Ukraine]. Scientific Bulletin of UNU. Series: International economic relations and world economy, vol. 12(2), pp. 157-160.

56. Belousova, I. A., Zakharov, A. I., Kirichenko, A. A., \& Prygunov, P. Ya. (2011). Ekonmicheskaya bezopasnost'. Novaya paradigma formirovaniya i obespecheniya [Economic security. New paradigm of formation and provision]. Odessa: Institute of Creative Technologies. (in Russian)

57. Jaremenko, S. (2005). Ekonomichna bezpeka bankiv [Economic security of banks]. Bulletin of the Academy of Sciences of Higher Education of Ukraine, no. 4 , pp. 26-34. 
58. Jaremenko, S. M. (2010). Zabezpechennja ekonomichnoji bezpeky dijal'nosti bankiv [Ensuring the economic security of banks] (PhD Thesis), Kiyv: Kyiv National Economic University named after Vadym Hetman.

59. Laptiev, S., Sidak, V., Mihus, I., \& Koval, Y. (2019). Actions to improve crisis management of economic security of banking institutions at the national level. Management mechanisms and development strategies of economic entities in conditions of institutional transformations of the global environment : in $2 \mathrm{vol} . /$ ed. by M. Bezpartochnyi. Riga: ISMA University: "Landmark" SIA, 2019. vol. 2, pp. 216-224.

60. Alessi, L., \& Detken, C. (2009). "Real time" early warning indicators for costly asset price boom/bust cycles Retrieved from: http://www.suomenpankki.fi/ pdf/162869.pdf (accessed 17 March 2020).

61. Borio, C., \& Lowe, Ph. (2002). Asset prices, financial and monetary stability: exploring the nexus. Retrieved from: http://www.bis.org/publ/work114.pdf (accessed 17 March 2020).

62. Borio, C., Drehmann, M. (2009). Towards an operational framework for financial stability: "fuzzy" measurement and its consequences. URL: http://www.bis.org/publ/work284.pdf (accessed 17 March 2020).

63. Caprio, Jr. G., \& Klingebiel, D. (1999). Episodes of systemic and Borderline financial crises. World Bank. $19 \mathrm{p}$.

64. Eichengreen, B., \& Rose, A. (2008). Contagious currency crises. Changes in Exchange Rates in Rapidly Development Countries: Theory, Practice, and Policy. Chicago : University of Chicago Press, pp. 29-55.

65. Laptiev, S., Mihus, I., \& Koval, Y. (2018). Improving the methodical approach to evaluation of economic security of banking institutions of Ukraine. Kosice security revue, no. 2, pp. 30-40. 